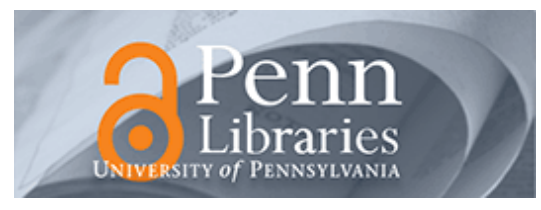

University of Pennsylvania

ScholarlyCommons

\title{
Credit Constraints, Job Mobility, and Entrepreneurship: Evidence From a Property Reform in China
}

Shing-Yi Wang

University of Pennsylvania

Follow this and additional works at: https://repository.upenn.edu/bepp_papers

Part of the Public Affairs, Public Policy and Public Administration Commons, and the Real Estate Commons

\section{Recommended Citation}

Wang, S. (2012). Credit Constraints, Job Mobility, and Entrepreneurship: Evidence From a Property Reform in China. The Review of Economics and Statistics, 94 (2), 532-551. http://dx.doi.org/10.1162/

REST_a_00160

This paper is posted at ScholarlyCommons. https://repository.upenn.edu/bepp_papers/139

For more information, please contact repository@pobox.upenn.edu. 


\title{
Credit Constraints, Job Mobility, and Entrepreneurship: Evidence From a Property Reform in China
}

\author{
Abstract \\ This paper provides new evidence on the impact of private property rights and employer-provided housing \\ on entrepreneurship. I find an increase in self-employment following a reform in urban China that allowed \\ state employees who were renting state-owned housing the opportunity to buy their homes at subsidized \\ prices. I develop a model of job choice to test two mechanisms that might explain how the reform \\ increased entrepreneurship. I find evidence that the reform reduced labor mobility costs and alleviated \\ credit constraints by allowing households to capitalize on the value of the real estate.

\section{Disciplines} \\ Public Affairs, Public Policy and Public Administration | Real Estate
}




\title{
CREDIT CONSTRAINTS, JOB MOBILITY, AND ENTREPRENEURSHIP: EVIDENCE FROM A PROPERTY REFORM IN CHINA
}

\author{
Shing-Yi Wang*
}

\begin{abstract}
This paper provides new evidence on the impact of private property rights and employer-provided housing on entrepreneurship. I find an increase in self-employment following a reform in urban China that allowed state employees who were renting state-owned housing the opportunity to buy their homes at subsidized prices. I develop a model of job choice to test two mechanisms that might explain how the reform increased entrepreneurship. I find evidence that the reform reduced labor mobility costs and alleviated credit constraints by allowing households to capitalize on the value of the real estate.
\end{abstract}

\section{Introduction}

$\mathrm{S}_{\mathrm{i}}$ TATE-OWNED housing represents a large share of housing stock in low-income countries. Data from the United Nations Human Settlements Indicators (United Nations, 2001) suggest that residents in state-owned housing represent $18 \%$ of households in Africa, $16 \%$ in Asia, and $8 \%$ in Latin America. Unlike public housing in high-income countries, which is provided as a welfare benefit to low-income households, the bulk of state-owned housing in Africa and Asia is provided as an in-kind benefit to employees in the government and in state-owned enterprises. While the potential problems of undersupply, corruption, and poor maintenance have been widely recognized (Fishback, 1992; Wang \& Murie, 1999), there is a remarkable lack of evidence that measures the labor market consequences of such housing programs or that explores the mechanisms through which the effects work.

This paper uses a reform of employer-provided housing in China as a natural experiment to analyze how the state provision of housing affects labor market decisions. Beginning in 1994, the reform offered state employees who were provided rental housing by their employers the opportunity to purchase their homes at subsidized prices. It was a largescale program that affected over $40 \%$ of urban households in China. In this paper, I focus on the impact of the property reform on the decision to enter into entrepreneurship because entrepreneurs are regarded as key agents in fostering the innovation and investment necessary for economic development (Banerjee \& Newman 1993). In addition to showing that the reform increased self-employment, I explore two mechanisms through which state ownership of property might affect entrepreneurship. First, in a credit-constrained environment, the privatization of state assets could allow individuals to capitalize on the value associated with the real estate in

Received for publication June 29, 2009. Revision accepted for publication September 29, 2010.

* New York University.

I am grateful to Chris Udry, Mark Rosenzweig, Joe Altonji, and Hanming Fang for their constructive advice and encouragement. This paper has also benefited from comments from Santosh Anagol, A. V. Chari, Peter McHenry, participants at various seminars, and two anonymous referees. All errors are my own. ways that they cannot as renters. ${ }^{1}$ Second, the unbundling of housing from the employment decisions of individuals could increase aggregate job mobility, including transitions into entrepreneurship.

The first mechanism focuses on the institutions that allow the capital embedded in property to be used in a productive manner. Economic research supports the importance of private property rights for economic development (Acemoglu, Johnson, \& Robinson, 2001), as well as for householdlevel decisions regarding labor (Field, 2007) and investment (Besley, 1995; Field, 2005; Galiani \& Schargrodsky, 2010). This paper contributes to the existing property rights literature by offering an empirical test of the idea that private property rights allow individuals to fully capitalize on the value of their property. De Soto (2000) popularized the idea that the real estate occupied by urban squatters contains vast amounts of potential wealth that could be transformed into capital for entrepreneurial ventures through the formalization of property rights. The focus of this paper is on the creation of private property rights over the stock of state-owned housing rather than the formalization of property rights for urban squatters.

The ability to access the value associated with property is relevant for entrepreneurial ventures in the presence of credit market imperfections. Evidence for severe credit constraints has been found for firms (Banerjee \& Duflo, 2004, in India; De Mel, McKenzie, \& Woodruff, 2008, in Sri Lanka; McKenzie \& Woodruff, 2006, in Mexico), as well as for agriculture (Udry \& Anagol, 2006, in Ghana). This paper is more closely aligned with the credit constraints literature that examines the individual-level decision to enter into entrepreneurship. Research by Evans and Jovanovic (1989) in the United States, Paulson and Townsend (2004) in Thailand, and Djankov, Qian, Roland, and Zhuravskaya (2006) in China find a positive relationship between preexisting wealth and the probability of entry into entrepreneurship. The notion that wealth predicts entrepreneurship is seen as evidence that wealthy individuals are able to finance their business ideas, while less wealthy individuals are unable to raise the capital necessary to start up or maintain their business ventures. However, if wealth is correlated with unobserved ability, then there can be a positive correlation between wealth and entrepreneurship in the absence of credit market imperfections. Research that attempts to instrument for wealth with inheritances and housing prices provides mixed results (Hurst \& Lusardi, 2004; Fairlie \& Krashinsky, 2006). However, inheritances are arguably not exogenous, and the

1 The model by Banerjee and Newman (1993) demonstrates how credit market imperfections can lead to barriers to entry for potential entrepreneurs, and have negative effects on aggregate economic growth and the income distribution. 
changes in housing prices used in these papers may be too small to produce a salient wealth effect. I use an exogenous change in access to housing wealth to separate the effect of credit constraints from omitted variables that affect an individual's decision to start a small business. Unlike the small-scale changes in wealth used in other papers, the value associated with the property occupied by state housing tenants was quite large.

In addition to credit constraints, this paper considers job mobility as a second factor that affects entry into entrepreneurship. The special features of the housing system in China make it both interesting and necessary to consider job mobility when analyzing the labor market choices of individuals in China. The bundling of housing benefits with a specific employer in the state sector could have reduced labor mobility because individuals were unable to stay in their current homes if they switched jobs. To my knowledge, this paper is one of the first analyses of the economic effects of employer-provided housing benefits. ${ }^{2}$ A related literature on in-kind benefits and job mobility focuses on the provision of health insurance in the United States (Madrian, 1994; Kapur, 1998; Buchmueller \& Valleta, 1996; Gruber \& Madrian, 2002). For both health insurance in the United States and housing provision in China, the level of employer-provided benefits does not directly reflect worker productivity. For example, American employees with large families receive greater compensation in the form of health insurance coverage than equally productive single workers. The methods of the health insurance literature do not apply to employerprovided housing because the outside cost of health insurance varies based on individual characteristics such as preexisting conditions, whereas market housing prices do not vary across individuals. My research is also related to work on the labor market effects of different systems of housing, such as welfare housing (Hughes \& McCormick, 1987) and rent control (Svarer, Rosholm, \& Munch 2004). My analysis focuses on housing that is tied to employment rather than to a neighborhood or a specific apartment.

My baseline identification strategy uses a differences-indifferences approach in comparing the outcomes of the same individuals before and after the reform, as well as relative to a control group of similar individuals. I use both a state sector and a private sector comparison group and find substantial treatment effects relative to both groups. While the treatment group is not exogenously determined, the panel structure of the data set allows me to provide empirical support for the identification assumption of parallel trends in self-employment between the two groups before the reform.

To understand the mechanisms that underlie the program's effect on entrepreneurship and the identification issues in my empirical work, I develop a theoretical model of job choice that incorporates features of the Chinese labor market. The

\footnotetext{
${ }^{2}$ Wang (2011) measures the degree of misallocation associated with the Chinese system of employer-provided housing and the equilibrium housing price effects of the removal of this type of housing misallocation.
}

model allows heterogeneity in unobserved individual characteristics such as entrepreneurial ability and connections in the state sector. The framework provides insight into how individuals sort into different types of housing and employment sectors. It also yields predictions that allow me to examine the two mechanisms through which the sale of state-owned housing during the housing reform could have led to an increase in entrepreneurship.

Using data from the China Health and Nutrition Survey, my estimates suggest that the vast majority of residents in state-owned housing chose to purchase their homes at the subsidized price. Furthermore, the reform increased the log odds that former state housing residents entered into selfemployment by two times. The data also provide strong evidence of labor mobility among former residents of stateowned housing, as well as some evidence of growth in the amount of business capital that they owned. An extrapolation of the estimates suggests that the property reform freed around 10 billion RMB from former state-owned housing for productive enterprises. This represents an increase of $14 \%$ on an estimated 67 billion RMB of capital investment in urban household enterprises in 1993.

The results on general labor mobility presented in this paper are consistent with Iyer, Meng, and Qian's (2009) subsequent examination of various types of housing reforms in China. ${ }^{3}$ However, their paper differs in its conclusion that there was no effect on entrepreneurship or credit constraints. Their identification strategy assumes that city-level reforms in the majority of urban areas occurred prior to 1994 and gave households in state-owned housing the opportunity to purchase their units as early as $1988 .{ }^{4}$ However, the summary statistics for home ownership rates in their data and in the CHNS are not consistent with this assumption; both sets of data indicate that the rise in home ownership was completely flat until 1993. Furthermore, their lack of results may be explained by an identification strategy that compares very different types of reforms across cities. The literature (discussed in the next section) indicates that some small-scale experiments occurred prior to 1994 but they varied in their focus on rent reform or privatization and differed widely in their pricing and property rights. Given the large size of their standard errors, it is not possible to reject that the results are consistent with the findings in this paper.

The following section presents an overview of the institutional background. Section III offers the theoretical framework. Section IV discusses the data and the empirical methodology. After I establish that the reform increased entrepreneurship in section $\mathrm{V}$, the next two sections use the predictions of the model to examine whether the increase can be explained by the unbundling of housing from employment (section VI) or the alleviation of credit constraints (section VII). Section VIII concludes.

\footnotetext{
3 Their work follows a previous version of this paper (Wang, 2008).

${ }^{4}$ The identification strategy also relies on differences in the timing of implementation across cities, but the endogeneity of the decision of when to privatize between 1988 or 1997 is not addressed.
} 


\section{Institutional Background}

\section{A. Socialism and Early Reforms}

Upon taking control in 1949, the Communist Party nationalized land in urban areas and established a system that guaranteed jobs for all workers. Households with private ownership of homes retained full property rights to their residences, but the government established public ownership of all new housing stock. Public housing stock was allocated to urban residents through state work units, and nominal rents were charged.

Following the death of Chairman Mao in 1976, the new leadership initiated a gradual reform of the socialist system toward a mixed economy. A reform of the housing system was considered because the government recognized serious problems in the state provision of housing, including shortages, poor management, and corruption in the distribution (Wang \& Murie, 1999). Private construction of housing was allowed, and the supply of private housing expanded. The first experiments on the public housing system entailed the sale of newly built apartments at construction cost in Xian and and Nanning in 1979. During the 1980s, several other small-scale housing experiments were piloted in different cities. These included a program that split the cost of housing between workers and state work units and a voucher system in which employees paid additional rent if their housing allotment exceeded the value of the voucher. One of the most serious proposals outlined by the federal government included simultaneously increasing rents and wages and encouraging state tenants to buy their homes at full cost (Pudney \& Wang, 1995). The small-scale attempts at privatizing housing failed because people found the prices too high.

After the political protests and subsequent military crackdown in Tiananmen Square in 1989, the central government shifted the discussion about housing reform toward rent increases rather than privatization. The government realized its past ideas for privatization were financially infeasible as well as politically destabilizing (Davis, 1993). Davis's interviews with urban residents confirm that the central and municipal governments hid their plans for full commodification of urban housing assets from most of the population through the early 1990s. While the experimentation in the 1980s clearly demonstrated the government's interest in housing reform, qualitative research suggests that the urban population did not foresee the timing and specific nature of the reform. In section VA, my empirical analysis confirms that anticipation of the reform did not affect prereform labor market choices.

\section{B. Privatization of Public Housing Units}

In July 1994, the State Council outlined the procedures for state employers to sell public housing units to sitting tenants in urban areas throughout the country. Individuals in state-owned housing were given the opportunity to buy full or partial property rights to their current homes. Partial property rights included use rights for perpetuity, the right to bequeath, and the right to use the home as collateral for loans. After five years of ownership, individuals with partial property rights gained the right to sell the home but shared the profits from the sale with their work units. ${ }^{5}$ In contrast, those purchasing full property rights faced no restrictions in the use or sale of their homes and retained all profits.

Learning from the public response to housing experiments in the 1980s, the government allowed work units to set prices for their housing stock below market value with additional discounts based on seniority. According to the China News Analysis (“Guangxi's Housing Reform Success," 1998), most buyers paid less than $15 \%$ of the market value for their homes. While the option to buy the home had no specified time limit, the government encouraged immediate purchase by specifying a schedule of price increases over time. As added incentive to purchase homes, the reform included proposals to increase rents in state-owned housing units by up to fifteen times to bring them closer in line with market rates. The generous price subsidies allowed most households to buy the homes outright. Households without the cash to purchase their homes had the incentive to take mortgage loans because they would gain the difference between the market value and the government sale price. Households in state-owned housing were not so constrained that they were unable to raise the amounts necessary to purchase their homes. Thus, the credit constraints hypothesis examined in this context is whether some households required an amount of capital to start a business that was larger than the subsidized cost of the home and whether the substantial gap between the market value of the housing units and the price charged during the property reform allowed them to make business investments that they would have been otherwise unable to make.

The housing reform that began in 1994 transformed China into a country with one of the highest rates of home ownership in the world. The success of the reform in increasing the rates of home ownership among state employees is demonstrated in figure 1, which displays the rates of home ownership by the employment status of the household head. The trend for households headed by state employees demonstrates a dramatic increase in home ownership following 1993, while the trend for households headed by private employees is relatively flat.

Data from the Chinese Household Income Project covering urban areas in eleven provinces in 1995 indicate that the average difference between the market value and the price charged by the government was $24,462 \mathrm{RMB}$, which is more than two times the average annual wages of a household. ${ }^{6}$ While the

\footnotetext{
${ }^{5}$ In some cases, the subsequent sale of former public units had additional limitations. For example, apartments sold to public university employees who were located on campus could not be sold on the open market. On-campus property had to be sold back to the university or to other university employees. Such strict limitations on sale were not common outside university housing systems.

6 The calculation is based on the sample of 6,931 households in the Chinese Household Income Project of 1995, which was selected from a sample of 35,000 urban households from the State Statistical Bureau.
} 
Figure 1.-AgGregate TRENDS IN Home OWNERShIP IN URBAN AREAS

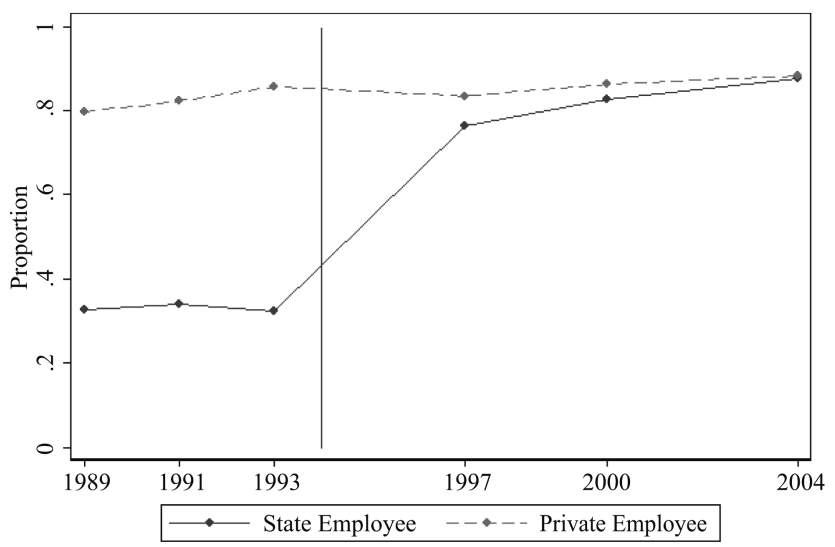

Source: China Health Nutrition Survey (CHNS).

terms of the sale of state housing assets were highly subsidized, the prereform rents charged by the government were also extremely subsidized. The average present discounted value of future rent subsidies under the prereform system is calculated to equal 20,500 RMB. ${ }^{7}$ This is roughly equivalent to the 24,462 RMB subsidy in the sale price during the reform. ${ }^{8}$ Thus, while the terms of the sale were subsidized, they did not imply a large wealth transfer; rather the reform allowed individuals to access and capitalize on the value associated with their homes that they had previously only been able to occupy. The effect of the housing reform operated through the transformation of use rights into private property rights rather than through a wealth effect associated with the terms of the sale.

While the value associated with each home was substantial, its relevance for entrepreneurship depends on whether the home equity could be accessed. There are at least three ways that individuals could access the value of their homes after the reform. First, after acquiring full property rights, individuals could sell their homes. Appendix table A3 shows the households that were given the opportunity to buy their state-owned rentals were more likely than other groups to change residences within the sample area following the reform. Although there were restrictions on outright sale among individuals who purchased partial property rights, they could still access the wealth by renting out rooms or using the home as collateral in loans from both formal and informal sources. ${ }^{9}$ An

\footnotetext{
7 This calculation is based on the assumption that individuals believed the current system would persist and on an expected life expectancy of 75 years for urban residents and a real interest rate of 2\% in China in 1994. The average age and prereform rent subsidy of state housing tenants used in the calculation are based on data shown in table 1.

8 In other words, state-owned housing tenants expected to receive a wealth transfer from the state in the form of subsidized rent every month. The reform converted the flow of those subsidies into an equivalent transfer of value that they could access immediately.

${ }^{9}$ Formal sector lending by banking institutions is less common in China than in developed countries such as the United States. However, evidence suggests that informal sector lending is common in China (Feder et al.,
}

Figure 2.-Urban AgGregate Trends in State Employment AND SELF-EMPLOYMENT

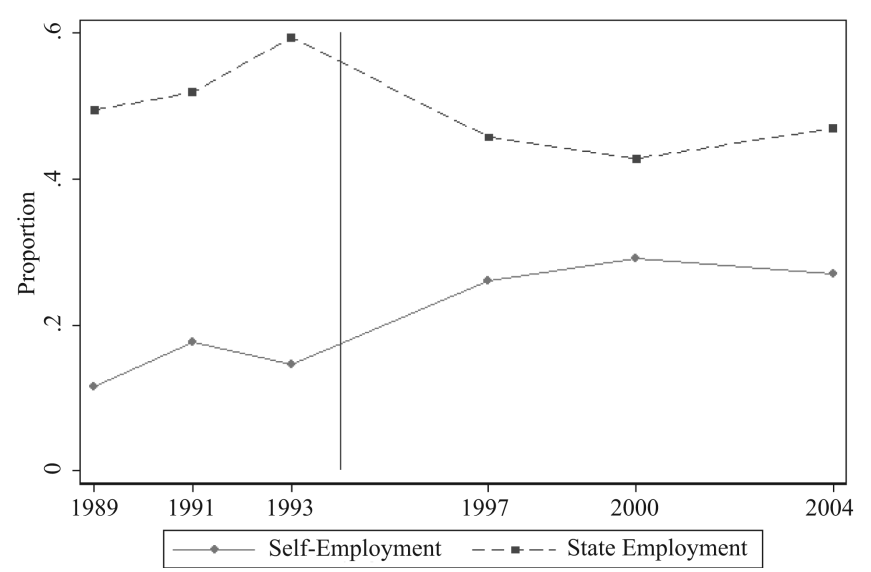

Source: CHNS.

article in the Financial Times (Kynge, 2002) emphasized the importance of loans collateralized by housing: "Having recently bought an apartment from his state employer at a steep discount, he felt galvanized to put his asset to work... . Mr. Yao is one of millions of Chinese discovering the delights of collateral. A boom in home ownership in most large cities over the past five years has furnished many people with their first genuinely valuable asset and the Chinese are proving enthusiastic borrowers." A Gallup poll on borrowing behavior in China in 2005 (Arora, 2005) found that personal borrowing to start or operate a business was the top reason that individuals go into debt $(42 \%$ of respondents).

Figure 2 shows rates of state employment and selfemployment in urban areas from 1989 to 2004 . The timeseries patterns provide visual evidence of a break in employment trends following the start of the reform in 1994 and are consistent with movement from the state sector into selfemployment. Aggregate employment in the state sector was $8 \%$ lower in the three periods after the reform than before, and self-employment rose by $12 \%$.

\section{Theoretical Framework}

\section{A. A Model of Employment and Housing Choices}

I develop a static model of employment and housing decisions that incorporates elements of Evans and Jovanovic's (1989) model of entrepreneurial choice with liquidity constraints. Suppose the utility of individual $i$ employed in sector

1992). A 2004 survey by the Beijing Central University of Finance and Economics of twenty provinces estimated the amount of underground lending in China at $\$ 101$ billion, equivalent to $28 \%$ of the funds lent through formal sources ( $\mathrm{Li}, 2005)$. Further evidence indicates that loans from nonbank sources are often collateralized by assets including housing (Watts, 2005; Guo \& Mu, 1998). 
$l$ is a function of housing, $h_{i l}$, and nonhousing consumption, $C_{i l}$, is

$$
\max _{h_{i l}, k_{i l}} U\left(C_{i l}, h_{i l}\right)
$$

where $l \in\{s, p, e\}$ and $s$ indicates the state sector, $p$ the private wage sector, and $e$ entrepreneurship. The constraints differ by sector because the model allows borrowing only to finance capital, and capital investment is relevant only in the entrepreneurial sector. The budget constraint for a wage employee in the private or state sector is

$$
C_{i l}+q_{l} h_{i l}=Y_{i l}+r W_{i},
$$

and for an entrepreneur, it is

$$
\begin{aligned}
& r b_{i l}+C_{i l}+q_{l} h_{i l}=Y_{i l}\left(k_{i l}\right) \\
& k_{i l}=W_{i}+b_{i l} \\
& -W_{i} \leq b_{i l} \leq \lambda\left(q_{l} h_{i l}+W_{i}\right),
\end{aligned}
$$

where $k_{i l}$ is capital, $r$ equals the cost of borrowing plus $1, q_{l}$ is the price of a unit of housing, and the price of consumption is normalized to equal 1 . Individuals are credit constrained in their investment in capital and the net amount that they can borrow, given by $b_{i l}$. The net amount borrowed cannot exceed a proportion of their total wealth, which includes the value of their homes, $q_{l} h_{i l}$, and their liquid assets, $W_{i}$. The proportion is denoted by $\lambda$, where $0<\lambda<1$. If she chooses not to own capital $\left(k_{i l}=0\right.$ and $\left.b_{i l}=-W_{i l}\right)$, she can lend out her wealth. The amount the individual earns in sector $l$ is $Y_{i l}$. The utility function is assumed to be increasing and concave in both consumption and housing. Sorting into the three sectors is driven by differences in their housing compensation and earnings in the various sectors.

Wages in the private and state sectors are functions of individual $i$ 's set of observable characteristics, $x_{i}$, given by $Y_{i p}=y_{p}\left(x_{i}, \zeta_{i}\right)$ and $Y_{i s}=y_{s}\left(x_{i}, \psi_{i}\right)$, respectively, where $\zeta_{i}$ is an unobserved component of wages in the private sector and $\psi_{i}$ the unobserved component of state wages. The market price for a unit of housing for entrepreneurs and private wage employees is $q\left(q_{p}=q_{e}=q\right)$. Workers in the state sector receive an amount of housing allocation, $\widetilde{h}_{i}=\widetilde{h}\left(x_{i}, \mu_{i}\right)$, to rent for free $\left(q_{s}=0\right)$. The person's observable characteristics, $x_{i}$, and some unobservable characteristics, $\mu_{i}$, determine the amount of public housing that the individual receives. This reflects the evidence that the allocation of public housing units depended on observable worker characteristics such as job tenure and rank, as well as unobservable traits such as social connections (Logan \& Zhou, 1996). I assume that $\mu_{i}$ and $\psi_{i}$ are not perfectly correlated, and Appendix A provides empirical support for this assumption. Net entrepreneurial earnings are given by $Y_{i e}=\theta_{i} f\left(k_{i}\right)$, where $\theta_{i}$ reflects entrepreneurial ability and $f(\cdot)$ is the production function that is concave in the amount of capital invested in the business, $k_{i}$.
FIGURE 3.-CASE OF $Y_{p}>Y_{s}$

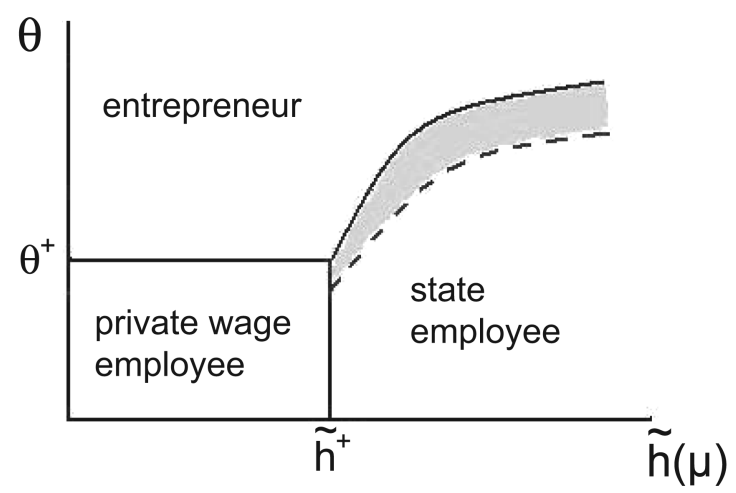

The total utility an individual derives from working in the state sector is given by $V_{i s}=U\left(Y_{i s}+r W_{i}, \widetilde{h}_{i}\right) .{ }^{10}$ The total utility of a worker in the private sector is $V_{i p}=U\left(Y_{i p}+r W_{i}-\right.$ $\left.q h_{i}^{*}, h_{i}^{*}\right)$, and $h_{i}^{*}$ solves the relevant first-order condition. The total utility of an entrepreneur is $V_{i e}=U\left(\theta_{i} f\left(\bar{k}_{i}\right)-r \bar{k}_{i}+\right.$ $\left.r W_{i}-q \bar{h}_{i}, \bar{h}_{i}\right)$, where the amount of housing chosen is such that

$$
\bar{h}_{i} \text { solves } \begin{cases}-q U_{c}+U_{h}=0 & \text { if } b_{i}^{*}<\lambda\left(q \bar{h}_{i}+W_{i}\right) \\ -q(1+r \lambda) U_{c}+U_{h}=0 & \text { if } b_{i}^{*}=\lambda\left(q \bar{h}_{i}+W_{i}\right) .\end{cases}
$$

The entrepreneur also selects the amount of capital to invest in her business. At an interior solution, the first-order condition with respect to $k$ yields $k_{i}^{*}$, which solves $\theta_{i} f^{\prime}\left(k_{i}\right)=r$. However, the maximum capital accessible for the entrepreneur is constrained such that $k_{i} \leq(1+\lambda) W_{i}+\lambda q \bar{h}_{i}$. Thus, $\bar{k}_{i}=\min \left\{k_{i}^{*}, k_{i}^{c c}\right\}$ where $k_{i}^{c c}=(1+\lambda) W_{i}+\lambda q \bar{h}_{i}$. For $k_{i}^{c c}<k_{i}^{*}$, we have that $\theta_{i} f\left(k_{i}^{c c}\right)<\theta_{i} f\left(k_{i}^{*}\right)$, and the total value of being an entrepreneur, $V_{i e}$, is lower for individuals with binding credit constraints. Thus, it is possible that a constrained individual chooses not to be an entrepreneur even though she would have if she were able to achieve the optimal level of capital investment, $k_{i}^{*}$. Credit constraints will produce a correlation between individuals' total wealth and their probability of entering entrepreneurship.

For a worker with given values of $W_{i}, x_{i}, \zeta_{i}$, and $\psi_{i}$ such that $y_{p}\left(x_{i}, \zeta_{i}\right)>y_{s}\left(x_{i}, \psi_{i}\right)$, her optimal choice across job sectors can be represented by the solid lines in figure $3 .{ }^{11}$ The values $\theta^{+}$and $\widetilde{h}^{+}$are the reservation values that delineate the choices of workers based on their unobserved heterogeneity in $\mu_{i}$ and $\theta_{i}$. More specifically, $\theta^{+}$is the value of $\theta_{i}$ at which

\footnotetext{
${ }^{10}$ This assumes that all state employees receive and accept the housing offered in the state sector. This simplification allows me to focus on the implications of employer-provided housing in the state sector and does not change the fundamental results of the model. In reality, many state employees live in private housing because they are waiting for a state housing assignment or because their preferences and budget constraints bring them to consume a level of housing that is different from their state assignment.

11 For an individual for whom $y_{p}\left(x_{i}, \zeta_{i}\right)<y_{s}\left(x_{i}, \psi_{i}\right)$, the choice simplifies to a binary choice between entrepreneurship and the state job. The individual will not choose the private sector because she will receive higher wages and a nonnegative housing benefit in the state sector.
} 
an individual is indifferent between private wage employment and self-employment. Similarly, $\widetilde{h}^{+}$is the reservation value of housing benefits needed to make the individual indifferent between working for the state or a private firm. Finally, for individuals with high draws of both $\theta$ and $\mu$, there are values of $\theta_{i}$ and $\widetilde{h}_{i}$ such that the individual is indifferent between entrepreneurship and state employment, $V_{i e}=V_{i s}$. This locus of points in $(\theta, \widetilde{h})$ space is determined by

$$
U\left(Y_{i s}+r W_{i}, \tilde{h}_{i}\right)=U\left(\theta_{i} f\left(\bar{k}_{i}\right)-r \bar{k}_{i}+r W_{i}-q \bar{h}_{i}, \bar{h}_{i}\right) .
$$

This is represented by the solid curve in figure 3 and defines the employment decision for workers with high levels of both $\theta_{i}$ and $\widetilde{h}\left(\mu_{i}\right) .^{12}$

As a result of the sorting process, individuals with higher levels of $\widetilde{h}(\mu)$ also have higher average levels of $\theta$. Holding constant other characteristics, individuals with high levels of $\theta$ and low levels of $\widetilde{h}(\mu)$ will work as entrepreneurs. Thus, high $\theta$ types will locate in the state sector only if their housing allocation $\widetilde{h}(\mu)$ exceeds the threshold level. A similar explanation applies to the relationship between $\widetilde{h}(\mu)$ and the unobservable factor, $\zeta_{i}$, that influences wages in the private sector. ${ }^{13}$ High levels of $\tilde{h}(\mu)$ observed in the state sector will also correspond to higher average amounts of $\zeta_{i}$.

\section{B. Theoretical Implications of the Housing Reform}

Loosening credit constraints increases the likelihood of self-employment by allowing individuals to move closer to $k^{*}$ from $k^{c c}$. In figure 3 , this would cause the curved line defined by equation (7) to shift down from the solid line to the dotted line. ${ }^{14}$ However, the housing reform loosens credit constraints only for state employees in public housing. Thus, only individuals in the shaded area in figure 3 (between the solid and dotted curved lines) shift from state employees to entrepreneurs. The credit constraints of private wage employees are not changed by the housing program, so none of the boundaries that determine their optimal employment decisions adjust.

By allowing workers to purchase their homes, the program removed the flow benefit of housing provision in the state sector. Because $\partial V_{i s} / \partial \tilde{h}>0$, the housing program reduced an individual's value of $V_{i s}$ and increased the likelihood of moving out of the state job. By decreasing the flow of housing benefits tied to state employment, $\widetilde{h}\left(\mu_{i}\right)$, to 0 for state employees who purchase the home, the reform shifts individuals left to their corresponding points on the $y$-axis and causes individuals to shift left in figure 3 . In this case, all state workers for whom $Y_{p}>Y_{s}$ will enter the private sector or entrepreneurship.

\footnotetext{
${ }^{12}$ The concave shape of the boundary is quite intuitive. The formal derivation of this result is available from the author.

${ }^{13}$ Figure 3 delineates the optimal employment decisions of individuals holding $\zeta_{i}$ constant. As $\zeta_{i}$ increases, the threshold levels $\theta^{+}$and $\widetilde{h}^{+}$will also increase and expand the area over which private wage employment is the optimal decision. It is possible to imagine a three-dimensional space that shows how $\zeta, \theta$, and $\widetilde{h}$ define the optimal employment choices.

${ }^{14}$ The corresponding calculations are available from the author.
}

As the theoretical framework demonstrates, there are two ways that the housing reform could increase transitions from employment in a state-owned enterprise into entrepreneurship. The creation of private property rights during the housing reform allowed individuals to invest more capital into a small business and increased the returns to entrepreneurship in the presence of credit constraints. On top of that, the unbundling of employment and housing provision reduced the nonwage benefits of state employment and increased the relative attractiveness of nonstate jobs.

I look for evidence for credit constraints in two empirical tests. The model predicts that the wealth that people hold and the value of their homes should predict selfemployment $\left(\partial V_{i e} / \partial\left(W_{i}+q h_{i}\right)>0\right)$ only if there are credit constraints. I examine variation in the postreform appreciation of housing prices to avoid the potential identification that arises if total wealth is positively correlated with unobservable entrepreneurial ability. More specifically, I use regional heterogeneity in the appreciation of housing prices to test whether housing wealth influenced entry into entrepreneurship. The second implication of the credit constraints hypothesis is that the property reform should have increased the levels of capital investment for prereform residents of public housing.

The model also generates two predictions to test whether the provision of housing benefits in the state sector was internalized by individuals in their labor market decisions. A reduction in the value of housing subsidies, $\tilde{h}$, induces individuals to shift out of the state sector and into both selfemployment and private wage employment. In contrast, a reduction in credit constraints predicts transitions only into self-employment and not into private wage jobs. Thus, the movement of state sector workers with housing benefits into private wage employment supports the unbundling hypothesis. A second prediction is generated from a simple extension of the model into a dynamic context. If the prereform system of providing state-owned housing with state jobs reduced labor mobility, we should see that the average wage gains accompanying job changes out of the state sector in the prereform period should be larger than the average gains in the postreform period. In other words, $w_{p, t}-w_{s, t-1}$ should be larger before the reform because individuals leaving the state sector would need additional compensation for the loss of subsidized housing.

Furthermore, the amount of rent subsidy that individuals received before the reform provides heterogeneity in the effects of bundling housing with state employment. The model demonstrated that individuals with more $\widetilde{h}$ should have higher levels of abilities in private wage employment, $\zeta$, and in entrepreneurship, $\theta$. Not only does the bundling hypothesis imply an increase in mobility that is not limited to transitions into entrepreneurship, but it also suggests that the effect on mobility should increase with prereform levels of $\widetilde{h}$. Similarly, not only should the wage gains be larger for individuals leaving the state sector before the reform, 
but the prereform wage gains of job changers should be positively correlated with $\widetilde{h}$.

\section{Data and Methodology}

\section{A. China Health and Nutrition Survey}

The panel data used in this analysis come from the China Health and Nutrition Survey (CHNS). The CHNS covers nine provinces (Guangxi, Guizhou, Heilongjiang, Henan, Hubei, Hunan, Jiangsu, Liaoning, and Shandong), which vary considerably in their geography and levels of economic development. The survey was sampled with a multistage, random cluster design. Counties were stratified into three levels of income, and a weighted sampling technique randomly selected four counties in each province. In addition, the data include the provincial capital and one low-income city. The data cover approximately 4,400 households and 16,000 individuals in the years 1989, 1991, 1993, 1997, 2000, and 2004. Thus, the data include three waves before and three waves after the beginning of the housing reform in 1994. While the survey contains both urban and rural households, the sample used in this analysis is limited to the urban sample because the housing reform was implemented only in urban areas. ${ }^{15}$ This paper focuses on labor market choices, so I limit the sample to working-age adults between 18 and 60 years old. Households with more than one generation of adults are not uncommon in urban China, but I restrict the individual-level analysis to household heads and spouses of heads. Furthermore, I exclude individuals who were enrolled in school or retired.

Entrepreneurs are defined as individuals who report their primary occupation as self-employed. This categorization excludes individuals who engage in entrepreneurial activities in addition to a full-time wage job. While less than $4 \%$ of adults in the CHNS report a secondary job, threequarters of this subsample engage in self-employment as their secondary labor market activity. Although not shown, the results in this paper are robust to the inclusion of people whose secondary job is self-employed. I also examine a definition of entrepreneurship as households that own a small business. This measure is highly correlated with individual self-employment. The results are similar, with slightly larger standard errors. Household business ownership is subject to more measurement error because the survey question changes between 1993 and 1997.

The theoretical model simplifies the employment structure of the Chinese economy by splitting the world into three sectors of employment: state, private, and self-employed. The survey allows individuals to categorize themselves into five sectors of employment: state, private, small collective, large collective, and other. In China, employment in collective enterprises is less relevant in urban areas than in rural areas. It is rare for collective work units to provide employees with

15 I define urban areas as neighborhoods where the majority of households have urban registrations. subsidized housing, so for the purposes of my analysis, it is not important to distinguish them from private wage employees. The empirical results presented in the paper are largely robust to the exclusion of collective employees from the sample and to the categorization of collective employees as state employees.

One of the main limitations of the data set is that there is no information on households, borrowing behavior. Thus, it is not possible to separate whether credit constraints are alleviated through borrowing against the value of the home or through other methods such as selling the former state housing unit for a smaller or rented home.

\section{B. Econometric Methodology}

To evaluate the causal impact of the policy change on individual outcomes, I use a differences-in-differences framework. The idea underlying the identification strategy is to compare the outcome not only before and after the reform but also between a treatment group and a control group. After the central announcement of the policy change occurred in July 1994, the start of the implementation of the housing reform varied at the regional level. I am unable to exploit this variation because the data set used in this analysis was not collected between 1993 and 1997, and all areas in the data set had implemented the reform by 1997.

The CHNS does not explicitly ask whether tenants of stateowned housing received the opportunity to buy their home during the reform, so I am unable to separate households that declined the opportunity to purchase a home from those that were not offered the opportunity.16 I identify the treatment group (State_Resident $89=1$ ) as all household heads and spouses of heads in state-owned housing with at least one member of the couple in state employment in 1989 or the next prereform wave in which data are available. ${ }^{17}$ Classification of individuals into the treatment and control groups occurs at the couple level. In other words, public housing tenants who are not employed in the state sector but married to state employees are categorized in the treatment category. A substantial fraction of state employees are married to other state employees, and it would not be possible to identify housing rights at the individual level for these couples.

One comparison group includes all household heads and spouses living in privately owned homes and not employed in a state-owned enterprise in 1989 (or the next prereform wave in which data are available). These individuals should not experience a direct effect from the reform of state-owned housing. I also define a second comparison group that encompasses household heads and spouses not living in state-owned housing but with at least one member in state employment in

\footnotetext{
${ }^{16}$ Over $80 \%$ of households living in state-owned housing in 1993 transitioned into private housing by 1997 , so any bias in the estimates would not be large.

17 In other words, in cases where the data are missing for 1989, treatment status is defined with the next earliest prereform wave (1991 or 1993) for which data are available.
} 
TABLE 1.-Summary Statistics IN 1993

\begin{tabular}{|c|c|c|c|}
\hline & Treatment: State_Resident $89=1$ & Control 1: Other State Employees & Control 2: Non-State Home Owners \\
\hline \multicolumn{4}{|c|}{ A: Individual Characteristics } \\
\hline \multirow[t]{2}{*}{ Male } & 0.53 & 0.56 & 0.53 \\
\hline & $(0.50)$ & $(0.50)$ & $(0.50)$ \\
\hline \multirow[t]{2}{*}{ Age } & 41.02 & 42.25 & 40.07 \\
\hline & $(8.98)$ & $(8.72)$ & $(5.54)$ \\
\hline \multirow[t]{2}{*}{ Married } & 0.98 & 0.99 & 0.98 \\
\hline & $(0.14)$ & $(0.11)$ & $(0.14)$ \\
\hline \multirow[t]{2}{*}{ Years of education } & 10.26 & $8.15^{*}$ & $7.25^{*}$ \\
\hline & (3.43) & $(3.62)$ & (3.37) \\
\hline \multirow[t]{2}{*}{ Real hourly wage } & 0.62 & 0.72 & $0.90^{*}$ \\
\hline & $(0.49)$ & $(0.56)$ & $(0.70)$ \\
\hline \multirow[t]{2}{*}{ Service occupation } & 0.17 & $0.28^{*}$ & $0.21^{*}$ \\
\hline & $(0.38)$ & $(0.45)$ & $(0.40)$ \\
\hline \multirow[t]{2}{*}{ Private wage employed } & 0.10 & $0.30^{*}$ & $0.57^{*}$ \\
\hline & $(0.30)$ & $(0.46)$ & $(0.50)$ \\
\hline \multirow[t]{2}{*}{ Self-employed } & 0.02 & $0.08^{*}$ & $0.40^{*}$ \\
\hline & $(0.12)$ & $(0.29)$ & $(0.49)$ \\
\hline \multirow[t]{2}{*}{ Observations } & \multirow{2}{*}{\multicolumn{2}{|c|}{ B: Household Characteristics 233}} & 290 \\
\hline & & & \\
\hline \multirow[t]{2}{*}{ Household size } & 3.31 & $4.28^{*}$ & $4.38^{*}$ \\
\hline & $(0.86)$ & $(1.56)$ & (1.44) \\
\hline \multirow{2}{*}{ Rent subsidy per month } & 66.31 & 0.50 & $1.06^{*}$ \\
\hline & (64.68) & $(5.27)$ & (11.52) \\
\hline \multirow[t]{2}{*}{ Durable nonhousing assets } & 3,522 & 3,693 & 4,364 \\
\hline & $(2,339)$ & $(8,129)$ & $(9,237)$ \\
\hline \multirow[t]{2}{*}{ Cadre in household } & 0.49 & $0.28^{*}$ & $0.18^{*}$ \\
\hline & $(0.72)$ & $(0.55)$ & $(0.28)$ \\
\hline \multirow[t]{2}{*}{ Positive capital holdings } & 0.03 & $0.17^{*}$ & $0.24^{*}$ \\
\hline & $(0.17)$ & $(0.38)$ & $(0.43)$ \\
\hline \multirow[t]{2}{*}{ Capital } & 21.06 & $78.73^{*}$ & $260.9^{*}$ \\
\hline & (307) & $(8,129)$ & $(1,199)$ \\
\hline \multirow[t]{2}{*}{ Head and spouse working } & 0.68 & $0.46^{*}$ & $0.57^{*}$ \\
\hline & $(0.47)$ & $(0.50)$ & $(0.50)$ \\
\hline \multirow{2}{*}{ Head and spouse state employed } & 0.67 & $0.21^{*}$ & $0.01^{*}$ \\
\hline & $(0.47)$ & $(0.41)$ & $(0.11)$ \\
\hline \multirow[t]{2}{*}{ Male state employed only } & 0.16 & $0.41^{*}$ & $0.03^{*}$ \\
\hline & $(0.36)$ & $(0.49)$ & $(0.36)$ \\
\hline \multirow[t]{2}{*}{ Female state employed only } & 0.06 & 0.05 & $0.01^{*}$ \\
\hline & $(0.23)$ & $(0.21)$ & $(0.09)$ \\
\hline Observations & 395 & 217 & 239 \\
\hline
\end{tabular}

1989 (or the next prereform wave in which data are available). There are a few anecdotal accounts of state-owned enterprises offering monetary compensation to employees not living in public housing at the time of the reform to offset the associated loss for workers on the waiting list for public housing allocations. However, the evidence suggests that this compensation was not universal and the value did not approach the large transfer associated with the subsidized home sale. Furthermore, any wealth transfer to individuals in the state-employed control group would bias the estimates toward accepting the null hypothesis of equality in the outcome between the treatment and the control group. The state-employed control group also offers the advantage of absorbing other changes occurring in the state sector around the time of the housing reform. Thus, this control group removes the effect of changes in the wage structure, increases in layoffs in the public sector, or decreases in the provision of other in-kind benefits.

Table 1 presents summary statistics for the groups in the year immediately before the implementation of the reform. The treatment group is statistically similar to the control groups along several dimensions, including gender, age, marital status, and durable nonhousing assets (which equals the sum of a household's self-reported market value of durable goods but does not include housing or financial assets). ${ }^{18}$ As expected, the treatment group is different from the control groups along a number of labor market characteristics. Households living in state-owned housing in 1993 have more members who hold positions as cadres. ${ }^{19}$ The real hourly wage of individuals in the treatment group is significantly lower than the privately employed control, but not significantly different from the control group of individuals in state employment. ${ }^{20}$ The rent subsidy is calculated as the difference between the self-reported market rental value and the rent paid per month. It is $66 \mathrm{RMB}$ per month for the treatment

\footnotetext{
18 Variables in units of RMB are converted into real 1990 RMB using the GDP deflator for mainland China from the United Nations.

${ }^{19}$ Cadres hold administrative or managerial positions in state-owned enterprises, government or the Communist Party.

20 The hourly wage is calculated as the sum of an individual's average monthly wage, one-twelfth of the annual bonus, and earnings from labor provided to a collective, all divided by average hours worked per month.
} 
group and approximately 0 for both control groups. The average levels of private wage employment, self-employment, and capital assets are lowest in the treatment group, and the state control group is more similar to the treatment group than the private control group. ${ }^{21}$

The treatment group has more education than the other groups. Individuals in the treatment group have an average of 10.3 years of education, which is 2.1 to 3.0 years more than the average in the control groups. This difference raises two potential concerns about the identification strategy. While I can control for differences in observed characteristics such as education, it is possible that my estimates reflect time-varying returns to education and other observable characteristics. This potential issue is addressed in section VIB. The second potential concern is that differences in observable characteristics may suggest the presence of differences in unobservables. The panel structure of the data allows me to remove the effects of any unobservable factors that are time invariant through the inclusion of individual fixed effects. The data indicate that observable characteristics and individual fixed effects explain approximately $80 \%$ of the variation in prereform housing subsidies among state employees (see table A1). Furthermore, I will show that the empirical results do not support this explanation.

\section{Main Results}

\section{A. Impact on Entrepreneurship}

The regressions with binary outcomes in this analysis are estimated with a logistic regression. Because the mean rate of self-employment is low, the logistic model will perform better than a linear probability model. The theoretical model suggests that the proper estimating equation includes individual fixed effects to control for the unobserved time-invariant characteristics, $\theta_{i}, \zeta_{i}, \psi_{i}$, and $\mu_{i}$, that affect decisions regarding housing and employment. The baseline panel differencesin-differences estimator is implemented as a logistic regression of the form 22

$$
\begin{aligned}
\operatorname{Pr}\left(y_{i t}=1\right)= & g\left(\alpha_{1} \text { State_Resident }_{8} 9_{i} * \text { Post }_{t}+\alpha_{2} \text { Post }_{t}\right. \\
& \left.+\alpha_{\mathbf{4}} \mathbf{x}_{\mathbf{i t}}+\gamma_{i}+\epsilon_{i t}\right),
\end{aligned}
$$

where $y_{i j t}$ is a dummy variable for self-employment for individual $i$ in year $t$, State_Resident $89_{i}$ identifies the treatment group, Post $_{t}$ is a dummy variable that equals 1 in the three periods following the reform, and $\gamma_{i}$ are individual fixed effects. The vector of covariates, $\mathbf{x}_{\mathbf{i t}}$, is a quadratic in age. The coefficient, $\alpha_{1}$, is the estimated effect of the housing program. The fixed-effects logit has the disadvantage of not yielding

\footnotetext{
${ }^{21}$ Capital is the self-reported amount of productive assets that the household owns.

22 For the fixed-effects estimator, the logit model is generally preferred over the probit model because the fixed-effects probit is computationally more difficult to implement and its estimates are inconsistent for a small number of time periods (Wooldridge, 2002a).
}

\begin{tabular}{|c|c|c|}
\hline & $\begin{array}{c}\text { Control = State } \\
\text { Workers } \\
\text { (1) }\end{array}$ & $\begin{array}{c}\text { Control = Private } \\
\text { Workers } \\
(2)\end{array}$ \\
\hline State_Resident $89 \times$ Post & $\begin{array}{c}1.907 \\
{[0.743]^{*}}\end{array}$ & $\begin{array}{l}2.103 \\
{[0.702]^{* *}}\end{array}$ \\
\hline Post & $\begin{array}{c}0.042 \\
{[0.599]}\end{array}$ & $\begin{array}{c}0.253 \\
{[0.296]}\end{array}$ \\
\hline Age & $\begin{array}{c}0.290 \\
{[0.134]^{*}}\end{array}$ & $\begin{array}{c}0.194 \\
{[0.110]^{*}}\end{array}$ \\
\hline $\mathrm{Age}^{2}$ & $\begin{array}{c}-0.002 \\
{[0.001]}\end{array}$ & $\begin{array}{c}-0.002 \\
{[0.001]}\end{array}$ \\
\hline Observations & 421 & 970 \\
\hline
\end{tabular}

TABLE 2.-IMPACT OF THE REFORM ON SELF-EMPLOYMENT

irors clustered by household in brackets. Additional controls are individual fixed effects.

estimates of average partial effects without strong assumptions regarding the distribution of $\gamma_{i}$ (Wooldridge, 2002a). For the fixed-effects logit models, I report the results in coefficients, or log odds ratios, which are interpreted as the log of the relative odds of the outcome occurring for a group relative to another. ${ }^{23}$ Again, $\alpha_{1}$ is the coefficient representing the program effect. Throughout the paper, the standard errors are adjusted to allow clustering at the household level.

In table 2, the estimates suggest that the reform significantly increased the log odds of self-employment by 1.9 to 2.1 times for the treatment group relative to the state control group and the private control group, respectively. While the treatment group differs from the control groups along some characteristics, the two control groups also differ substantially from each other along those characteristics. Thus, the similarity in the coefficient estimates for the treatment group relative to the two control groups provides some reassurance that the controls and the fixed effects are removing the impact of any differences across groups. ${ }^{24}$

Identification of a panel differences-in-differences estimator requires a parallel-trends assumption, which assumes the gap in the outcome between the treatment and the control group would remain the same in the absence of the reform. In order to examine this assumption, I allow the effects of the program to vary over time by estimating the following more flexible fixed-effects logit regression:

$$
\begin{aligned}
\operatorname{Pr}\left(y_{i j t}=1\right)= & g\left(\alpha_{0}+\sum_{t \geq 1991} \beta_{t} \cdot \text { State_Resident } 89_{i}\right. \\
& \left.+\boldsymbol{\alpha}_{\mathbf{2}} \mathbf{x}_{\mathbf{i j t}}+\tau_{t}+\gamma_{i}+\epsilon_{i j t}\right) .
\end{aligned}
$$

Relative to the baseline model of equation (8), the flexible specifications allow us to examine differences in trends in

\footnotetext{
${ }^{23}$ The sample sizes of the fixed-effects logit results reflect the fact that identification of the coefficients of a fixed-effects logit is off of switchers (individuals whose value of $y_{i t}$ changes).

${ }^{24}$ Logit coefficients are scaled by the residual variation of the estimated equation (Amemiya, 1985). Comparison of coefficients across regressions depends on the assumption that the unobserved variation is the same across the samples. The results of a test proposed by Allison (1999) fail to reject the null hypothesis of equal residual variation for the two samples $\left(\chi^{2}=1.07\right)$.
} 
TABle 3.-Flexible Estimates of Program EfFect on Self-Employment

\begin{tabular}{|c|c|c|}
\hline & $\begin{array}{c}\text { Control }=\text { State } \\
\text { Workers } \\
\text { (1) }\end{array}$ & $\begin{array}{c}\text { Control = Private } \\
\text { Workers } \\
(2)\end{array}$ \\
\hline State_Resident $89 \times 1991$ & $\begin{array}{c}-0.553 \\
{[0.972]}\end{array}$ & $\begin{array}{c}-0.565 \\
{[0.916]}\end{array}$ \\
\hline State_Resident $89 \times 1993$ & $\begin{array}{c}0.892 \\
{[1.319]}\end{array}$ & $\begin{array}{c}1.236 \\
{[1.234]}\end{array}$ \\
\hline State_Resident $89 \times 1997$ & $\begin{array}{c}2.118 \\
{[1.376]}\end{array}$ & $\begin{array}{l}2.461 \\
{[1.324]^{*}}\end{array}$ \\
\hline State_Resident $89 \times 2000$ & $\begin{array}{l}1.590 \\
{[1.275]}\end{array}$ & $\begin{array}{c}2.308 \\
{[1.285]^{*}}\end{array}$ \\
\hline State_Resident $89 \times 2004$ & $\begin{array}{c}2.620 \\
{[1.425]^{*}}\end{array}$ & $\begin{array}{c}2.676 \\
{[1.376]^{*}}\end{array}$ \\
\hline 1991 & $\begin{array}{c}1.139 \\
{[0.391]^{* * *}}\end{array}$ & $\begin{array}{c}1.1728 \\
{[0.216]^{* * *}}\end{array}$ \\
\hline 1993 & $\begin{array}{c}0.938 \\
{[0.550]^{*}}\end{array}$ & $\begin{array}{c}0.625 \\
{[0.272]^{*}}\end{array}$ \\
\hline 1997 & $\begin{array}{c}1.299 \\
{[0.776]^{*}}\end{array}$ & $\begin{array}{l}1.013 \\
{[0.383]^{* * *}}\end{array}$ \\
\hline 2000 & $\begin{array}{l}1.996 \\
{[0.863]^{* *}}\end{array}$ & $\begin{array}{l}1.152 \\
{[0.457]^{* *}}\end{array}$ \\
\hline 2004 & $\begin{array}{l}2.309 \\
{[1.167]^{* *}}\end{array}$ & $\begin{array}{l}2.190 \\
{[0.552]^{* *}}\end{array}$ \\
\hline $\begin{array}{l}\chi^{2}: 91+93=97+00+04 \\
\text { Observations }\end{array}$ & $\begin{array}{c}6.28^{* *} \\
421\end{array}$ & $\begin{array}{l}8.35^{* * *} \\
970\end{array}$ \\
\hline
\end{tabular}

Significant at the ${ }^{* * *} 1 \%$ level, ${ }^{* *} 5 \%$ level, ${ }^{*} 10 \%$ level. Robust standard errors clustered by household in brackets. Additional controls are a quadratic in age and individual fixed effects. Chi-square test of equality between the prereform interactions (State_Resident $89 \times 1991$ and State_Resident $89 \times 1993$ ) and the postreform interactions (State_Resident $89 \times 1997$, State_Resident $89 \times 2000$, and State_Resident $89 \times$ 2004).

self-employment before and after the housing reform began in 1994. An estimate of $\beta_{1991}$ and $\beta_{1993}$ equal to 0 would show that the gap in the outcome between the treatment and control groups did not vary before the reform. Hence, it would support the key identification assumption that trends in selfemployment across the different groups would have been similar in the absence of the reform.

Table 3 presents the results from the flexible equations given by equation (9). The interaction with 1989 is omitted.25 In table 3, the coefficient estimates of the prereform interactions, State_Resident $89 \times 1991$ and State_Resident $89 \times 1993$, are small in magnitude and statistically equivalent to 0 . This indicates that relative to earlier wave, the prereform trends in self-employment of individuals in state-owned housing were not different from the trends for state-employed or privately employed individuals in private housing. The results support the identifying assumption that the prereform trends in selfemployment for residents of state housing were similar to residents in private housing. The magnitude and significance of the coefficients shift in 1997, the first survey wave following the start of the reform. Thus, individuals who had the opportunity to buy their residences from the state transitioned into entrepreneurship beginning in 1997 at a greater rate than individuals already living in private housing. A chi-square test reveals that the coefficients on State_Resident $89 \times 1991$ and State_Resident $89 \times 1993$ are significantly different from

\footnotetext{
25 The specification that omits both the 1989 and 1991 waves produces similar results with smaller standard errors (not shown). The decrease in the standard errors is not surprising given the larger size of the comparison group.
}

State_Resident $89 \times 1997$, State_Resident $89 \times 2000$, and State_Resident $89 \times 2004$ at the $5 \%$ level in both specifications. In comparing the interactions among each of the postreform years $(1997,2000,2004)$ and the treatment indicator, the coefficients are not statistically different from each other. This indicates that the conditional, postreform trends in self-employment were similar for the treatment and control groups.

\section{B. Specification Checks}

Time-varying returns to characteristics. In this section, I address the potential concern that the results are being driven by changes over time in the returns to observable characteristics along which the treatment group is different from the control groups. For example, the summary statistics demonstrated that the treatment group has higher average levels of education than the control groups. The results may reflect other changes, such as increased access to foreign markets that highly educated entrepreneurs are able to leverage more easily than individuals with lower levels of education. I deal with this concern in two ways. First, I include the interaction between education and Post directly in the regression. Second, I use a propensity score approach (Rosenbaum \& Rubin, 1983; Wooldridge, 2002a), which is a more general method that examines the impact of differences in characteristics in addition to education.

The first step of the propensity score procedure estimates the relationship between observable characteristics and the probability of being in the treatment group across all individuals in the sample. This estimated propensity score is included in the second-stage regression where it acts as the control function and contains all the information in the covariates that is pertinent in the estimation of the treatment effect. In the regression framework, I include both the interaction of the propensity score with the Post dummy. ${ }^{26}$ This removes any time-varying effect of differences in observable characteristics between the treatment and control groups on the coefficient on State_Resident $89 \times$ Post.

The first-stage estimates of being in the treatment group are shown in the first column of table A4 in the table appendix reports the self-employment estimates with time-varying controls for education (columns 3 and 4) and for the propensity to be in the treatment group (columns 1 and 2). In all cases, the estimates of State_Resident $89 \times$ Post remain quite similar to the coefficient estimates in the baseline regressions displayed in table 2 . The coefficient estimates of Propensity $\times$ Post indicate that individuals who are observably similar to treatment individuals but not directly affected by the housing sale are not more likely to enter into selfemployment as a result of the reform. In fact, the regression in column 2 suggests that state-employed individuals with similar characteristics to the treatment group are significantly less

\footnotetext{
26 This approach has the same effect as interacting all of the observable characteristics with Post but has the advantage of being more parsimonious.
} 
TABle 4.-Estimates FOR SElF-EMPloyment: Robustness ChECKS

\begin{tabular}{|c|c|c|c|c|c|c|c|c|}
\hline & \multicolumn{4}{|c|}{ Observable Differences Across Groups } & \multicolumn{2}{|c|}{ Attrition } & \multicolumn{2}{|c|}{ Serial Correlation } \\
\hline & $\begin{array}{c}\text { Control = State } \\
\text { (1) }\end{array}$ & $\begin{array}{l}\text { Private } \\
\text { (2) }\end{array}$ & $\begin{array}{l}\text { State } \\
(3)\end{array}$ & $\begin{array}{l}\text { Private } \\
\text { (4) }\end{array}$ & $\begin{array}{l}\text { State } \\
(5)\end{array}$ & $\begin{array}{l}\text { Private } \\
\text { (6) }\end{array}$ & $\begin{array}{l}\text { State } \\
(7)\end{array}$ & $\begin{array}{l}\text { Private } \\
\text { (8) }\end{array}$ \\
\hline State_Resident $89 \times$ Post & $\begin{array}{l}1.84 \\
{[0.71]^{* * *}}\end{array}$ & $\begin{array}{l}2.51 \\
{[0.74]^{* * *}}\end{array}$ & $\begin{array}{c}1.77 \\
{[0.74]^{*}}\end{array}$ & $\begin{array}{l}1.99 \\
{[0.72]^{* * *}}\end{array}$ & $\begin{array}{l}1.50 \\
{[0.60]^{* *}}\end{array}$ & $\begin{array}{l}1.85 \\
{[0.54]^{* * *}}\end{array}$ & $\begin{array}{c}1.80 \\
{[0.98]^{*}}\end{array}$ & $\begin{array}{l}2.06 \\
{[0.67]^{* * *}}\end{array}$ \\
\hline Propensity $\times$ Post & $\begin{array}{c}0.51 \\
{[1.76]}\end{array}$ & $\begin{array}{l}-2.43 \\
{[1.37]^{*}}\end{array}$ & & & & & & \\
\hline Education $\times$ Post & & & $\begin{array}{c}0.11 \\
{[0.09]}\end{array}$ & $\begin{array}{c}0.10 \\
{[0.07]}\end{array}$ & & & & \\
\hline Post & $\begin{array}{l}-0.10 \\
{[0.89]}\end{array}$ & $\begin{array}{c}1.01 \\
{[0.53]^{*}}\end{array}$ & $\begin{array}{c}-0.71 \\
{[0.84]}\end{array}$ & $\begin{array}{c}-0.45 \\
{[0.51]}\end{array}$ & $\begin{array}{r}-0.48 \\
{[0.47]}\end{array}$ & $\begin{array}{l}-1.16 \\
{[0.32]^{* *}}\end{array}$ & $\begin{array}{c}0.09 \\
{[0.68]}\end{array}$ & $\begin{array}{c}-0.15 \\
{[0.68]}\end{array}$ \\
\hline Observations & 421 & 963 & 421 & 963 & 435 & 972 & 144 & 232 \\
\hline
\end{tabular}

likely to be entrepreneurs. Overall, the impact of the reform on entrepreneurship remains robust to addressing changes in the returns to education and other observable differences between the treatment and the comparison groups.

Sorting into the treatment and control groups is not random, and a potential alternative explanation for the results is that a change in the returns to the time-invariant, unobservable characteristics occurred at the same time as the housing reform. For example, an increase in corruption during the period of the housing reform might increase the returns to state connections for an entrepreneur, and state connections are higher among the treatment group. However, the coefficient estimates of the treatment effect are similar relative to the two control groups. For a change in the returns to timeinvariant unobservables to be driving the estimates, a specific relationship in the unobservable characteristics among the treatment and control groups must hold. It would require that the average levels of the unobservable characteristics that influence the decision to enter into self-employment are similar between the two control groups but different from the treatment group. This seems unlikely because the stateemployed control group and the privately employed control group are significantly different from each other along several characteristics, such as education and household cadres.

Sample attrition. Selective attrition is an unavoidable and difficult concern with analyses that rely on panel data. While attrition in my sample of analysis is low in the first two waves following the launch of the longitudinal survey in 1989 (averaging less than 5\% each year), it increases substantially in the last three waves of the survey. Approximately $14 \%$ of the sample attrites between 1993 and 1997. Furthermore, the rates of attrition differ across the treatment and control groups, with the treatment group being more likely to leave in each wave following the reform. In the 1997 round, $18 \%$ of individuals in state-owned housing in 1993 had attrited compared with $7 \%$ of individuals privately employed in 1993 and $16 \%$ of state employees without state housing in the previous sample period. This is not surprising because the theoretical framework predicts an increase in mobility for the treated relative to the untreated group following the reform. However, sample attrition can bias the estimates of the impact of the housing reform on entrepreneurship.

I address the potential bias from sample attrition by using the inverse probability weighting (IPW) method. The key assumption underlying this method is that attrition is based on observable characteristics. ${ }^{27}$ The IPW method places more weight on individuals who are likely to attrite in order to create a sample that better reflects the original full sample. The procedure involves two steps. First, for every wave following 1989, I estimate the probability that each individual remains in the sample conditional on his or her presence in the previous samples. In other words, for each wave following the first, I estimate a logit regression where the dependent variable is whether the individual remained in the survey. The estimates are shown in table A5 in the Table Appendix. However, the predicted conditional probabilities are not representative of the original sample population. Wooldridge (2002b) shows that the inverse of the joint probability can be used as weights in the second step of the estimation with the joint probability calculated directly from the conditional probabilities.

Columns 5 and 6 of table 4 display the results using inverse probability weighting to correct for sample attrition. Comparing these results to the ones shown in table 2, the attritioncorrected estimates of State_Resident $89 \times$ Post imply a similar, though slightly smaller, effect of the housing reform on self-employment. These results depend on the assumption that conditional on the variables in the attrition equation, attrition is ignorable with respect to self-employment. While the evidence suggests that selection based on observables does not drive the results, the issue of sample attrition based on unobservables is an unsolvable problem for the identification strategy. Heckman's two-step estimator provides a method for handling attrition based on unobservables, but the procedure relies on finding an exclusion restriction in the selection equation. Unfortunately, the data set does not provide a variable that would plausibly predict attrition but not job mobility and other labor market choices in this context.

${ }^{27}$ This assumption is often called "ignorability of selection." See Wooldridge (2002a) or Wooldridge (2002b) for more details on inverse probability weighting. 
In the absence of an empirical method for addressing attrition based on unobservables, I suggest another approach to thinking about this problem. Preference for risk is a likely candidate for an unobservable trait that affects both moving out of the survey area and entry into entrepreneurship. If individuals with greater preferences for risk are more likely to become entrepreneurs and more likely to move far enough to leave the sample area, then the bias stemming from attrition based on risk preferences will be downward. Attrition based on risk preferences is likely to have a similar impact as attrition based on observables in working against finding a significant effect of the reform on entrepreneurship.

Serial correlation. Bertrand, Duflo, and Mullainathan (2004) find that differences-in-differences estimates that use several years of data may lead to substantial underestimates of the standard errors if serial correlation in the outcomes is not addressed. Following their approach, I collapse the six waves of data into two periods, prereform and postreform. The results for self-employment are shown in the last two columns of table $4 .{ }^{28}$ The coefficient estimates are similar in magnitude and significance to the corresponding estimates in the baselines regressions.

\section{Other Changes in the State Sector}

The mid-1990s was a time of continued economic growth, and the Chinese government introduced numerous policies to reform the socialist system. In this section, I consider alternative explanations for the rise in entrepreneurship. For another explanation to be plausible, it would not only have to occur at the same time as the housing reform, but its impact would have to affect state employees residing in public housing and private employees in a similar manner. Any reforms that affected all state employees or did not affect private employees would not explain the significant, positive effect on entrepreneurship that I find for the treatment group relative to the two control groups.

Privatization of state assets occurred as state-owned enterprises were converted into private companies. The firm-level reforms in the state sector resulted in numerous layoffs as newly privatized companies shed excess labor to achieve profitability. It is plausible that substantial layoffs would increase the rate of self-employment if some individuals preferred self-employment over unemployment. However, the layoffs that resulted from the reform of state-owned enterprises can explain the increase in self-employment only if state employees in the treatment group were more likely to lose their jobs than state employees in the control group and the break occurred around the same time as the housing reform. Unfortunately, the data in the CHNS are not ideal for considering this issue because the survey does not ask explicitly about recent lay-offs. The most related information in the

\footnotetext{
${ }^{28}$ The majority of the remaining results of the paper are robust to this correction for the issue of serial correlation. The exception is that the results of table 7 are no longer significant at the $10 \%$ level.
}

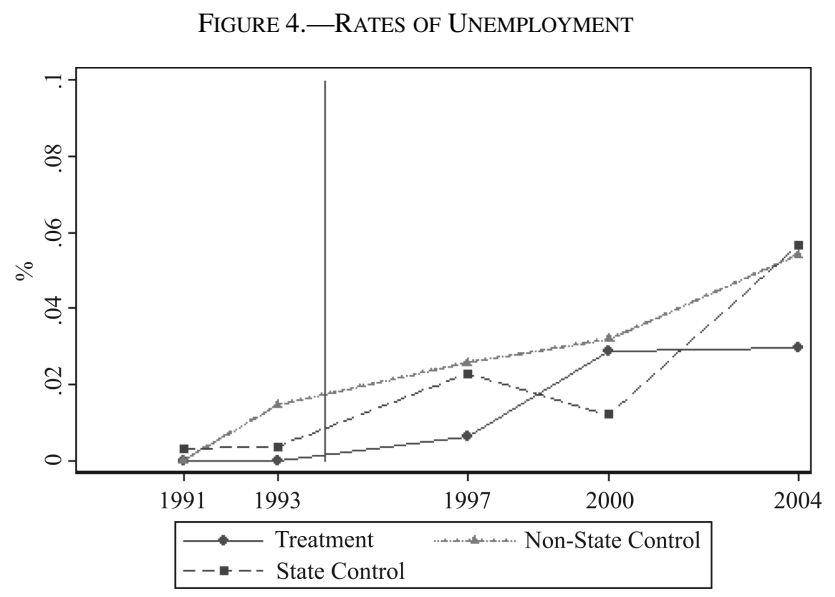

CHNS is unemployment status. Figure 4 shows the unemployment rates of individuals in the CHNS by treatment and control groups from 1991 to $2004 .{ }^{29} \mathrm{Tn}$ general, the rates of unemployment among the different groups moved together in a pattern that demonstrated increased unemployment from 1991 to 2004. A spike in the rate of change in unemployment for the treatment group relative to the control groups occurred between 1997 and 2000, but this was not the same time as the break in home ownership.

Given the limitations in the CHNS data, I also examine whether aggregate trends in layoffs in the state sector indicated that a break occurred between 1993 and 1997. Aggregate data on layoffs (xiagang) in state-owned enterprises indicate that the peak in layoffs occurred 1997, 1998, and 1999 (see table 1 in Giles, Park, \& Zhang, 2005). The share of workers laid off in state-owned enterprises ranged from 5.7\% to $7.2 \%$ between 1997 and 1999. In 1995, the corresponding figure was $3.2 \%$. Overall, unemployment data in the CHNS and the aggregate data both indicate that the bulk of layoffs in the state sector did not occur around the same time as the housing reform. However, the potential concern remains that anticipation of the coming layoffs in the state sector may have interacted with the effects of the housing reform to produce larger transitions into entrepreneurship than we would have seen in the absence of firm-level reforms and layoffs.

Other reforms were occurring in the state sector as the central government moved away from a socialist economic system that combined low wages with the provision of inkind benefits such as housing, health care, and child care. The value of health care and child care is quite small in comparison to housing costs, so even if the state monetized or removed health and child care benefits precisely around the time of the housing reform, it is likely that the effect of the housing program would dwarf other changes in benefits. Figure 5 displays the trends in health insurance coverage

\footnotetext{
${ }^{29}$ The CHNS did not ask about unemployment in the 1989 wave of the survey or about worker layoffs in any waves.
} 
Figure 5.-HEAlth InSURANCE COVERAGE

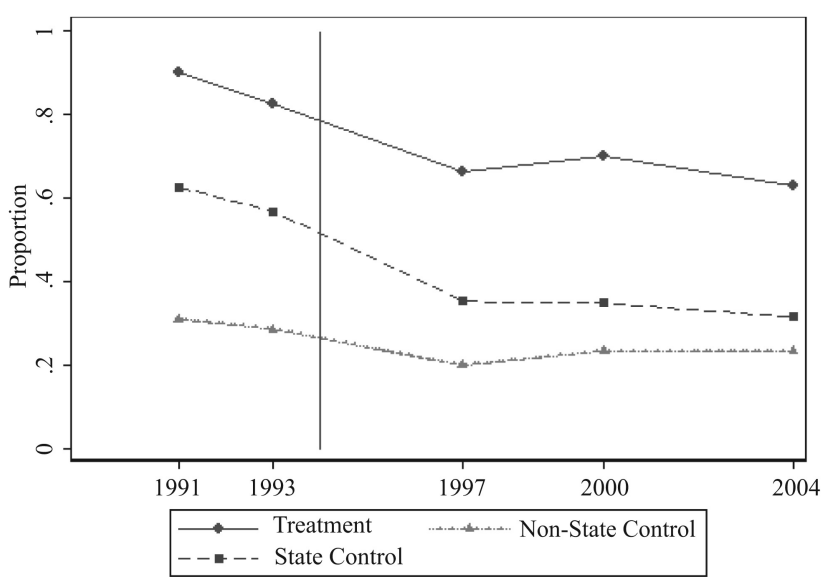

for the treatment and the control groups across time. ${ }^{30}$ The trends indicate that individuals in the treatment group were more likely to have some type of health insurance coverage than either of the control groups. The numbers of individuals with health insurance declined substantially over the early 1990s, but this reduction occurred more gradually than the housing reform. Not only does the timing of the decline precede the housing reform, but the trends are also moving in parallel for the three groups. This suggests that changes in health insurance provision in the state sector cannot explain the positive effect of the housing reform on entrepreneurship.

For the most part, the economic reforms pursued by the Communist government were embodied by Deng Xiaoping's phrase, "mozhe shitou guo he" ("crossing the river by feeling for stones"). The statement underscores the government's emphasis on a gradual reform process. The trends for unemployment and health insurance show gradual changes over time that were fairly similar for the treatment group and control groups.

\section{Impact of Bundling Housing and Employment}

Section V provided evidence that transitions into selfemployment among state housing residents increased relative to other groups as a result of the property reform. This section tests the predictions of the model associated with the hypothesis that the increase can be explained by the unbundling of housing from state employment.

\section{A. Mobility}

As the theoretical model suggests, we can determine whether the unbundling of housing from employment decisions contributed to the increase in entrepreneurship by testing whether the reform resulted in an increase in general mobility out of the state sector. In other words, the hypothesis on unbundling housing provision from employment

\footnotetext{
30 I have dropped the data for health insurance in 1989 because the survey question in 1989 was different from the subsequent years.
}

TABle 5.-Estimates of Private EMPloyment AND EMPloymEnt Status

\begin{tabular}{lccccc}
\hline \hline & \multicolumn{2}{c}{ Private Wage Employment } & & \multicolumn{2}{c}{ Work Status $=$ Employed } \\
\cline { 2 - 3 } \cline { 5 - 5 } & $(1)$ & $(2)$ & & $(3)$ & $(4)$ \\
\hline State_ResideWork89 & 2.042 & 0.322 & & -1.837 & -2.995 \\
$\quad \times$ Post & {$[0.419]^{* * *}$} & {$[1.039]$} & & {$[0.789]^{* *}$} & {$[2.480]$} \\
Post & -1.462 & -1.588 & & 0.567 & 0.652 \\
& {$[1.038]$} & {$[1.002]$} & & {$[1.282]$} & {$[1.360]$} \\
State_ResideWork89 & & & & -0.344 \\
$\quad \times$ Post $\times$ Log $(\widetilde{h})$ & & & & {$[0.305]$} \\
State_ResideSpouse89 & & & -0.118 & 0.637 \\
$\quad \times$ Post & & & $0.683]$ & {$[1.138]$} \\
State_ResideSpouse89 & & 0.592 & & 0.339 \\
$\quad \times$ Post $\times \log (\widetilde{h})$ & & {$[0.249]^{* *}$} & & {$[0.592]$} \\
$\chi^{2}$ test & & & & \\
$\alpha_{1}+\alpha_{3}$ & & & & $5.02^{*}$ \\
$\alpha_{4}+\alpha_{5}$ & & & & 1.50 \\
Observations & 912 & 895 & 803 & 762 \\
\hline
\end{tabular}

Coefficients shown. Significant at the $\sim_{\sim}^{* * *} 1 \%$ level, ${ }^{* *} 5 \%$ level, and ${ }^{*} 10 \%$ level. Robust standard errors clustered by household in brackets. $\log (\widetilde{h})$ is the logarithm of the average amount of rent subsidy received in the periods prior to the reform. Regressions also include a quadratic in age and individual fixed effects. In columns 1 and 2, the sample includes individuals who were state employed prior to the reform. In columns columns 1 and 2, the sample includes individuals who were state employed prior to the reform. In columns
3 and the sample includes individuals who were state employed prior to the reform and spouses of state employees living in state-owned housing prior to the reform.

can explain an increase in movement from state-owned enterprises toward private wage jobs, but the credit constraints story cannot. Thus, I estimate the following equation,

$$
\begin{aligned}
\operatorname{Pr}\left(y_{i t}=1\right)= & g\left(\alpha_{1} \text { State_ResideWork89 }_{i} \times \text { Post }_{t}\right. \\
& \left.+\alpha_{2} \text { Post }_{t}+\boldsymbol{\alpha}_{\mathbf{3}} \mathbf{x}_{\mathbf{i t}}+\gamma_{i}+\epsilon_{i t}\right),
\end{aligned}
$$

with the dependent variable as an indicator that takes a value of 1 if the individual is employed in a private wage job and 0 otherwise. The sample includes only individuals who were in state employment in 1989 (or the next prereform wave with data available). The previous analyses of the impact of the reform on self-employment have defined treatment at the couple level; thus, an individual residing in stateowned housing who was not employed in the state sector but married to a state employee has been categorized in the treatment group (State_Resident89 = 1). In this regression focusing on individual labor mobility, the treatment variable, State_ResideWork89, equals 1 if the individual was working for the state and residing in state-owned housing in 1989 (or the next prereform wave in which data is available). The results are presented in column 1 of table 5. The log odds of switching out of the state sector was 2.04 times higher for the residents of state housing than for the state-employed comparison group, and this is significant at the $1 \%$ level.

The model predicted that individuals with more generous rent subsidies before the reform should also have higher average abilities as entrepreneurs $\left(\theta_{i}\right)$ and private wage employees $\left(\zeta_{i}\right)$. I estimate

$$
\begin{aligned}
\operatorname{Pr}\left(y_{i t}=1\right)= & g\left(\alpha_{1} \text { State_ResideWork89 }_{i} \times \text { Post }_{t}\right. \\
& +\alpha_{2} \text { Post }_{t}+\alpha_{3}{\text { State_ResideWork } 89_{i}} \\
& \left.\times \text { Post }_{t} \times \tilde{h}_{i}+\alpha_{4} x_{\mathbf{i t}}+\gamma_{i}+\epsilon_{i t}\right)
\end{aligned}
$$

where $\widetilde{h}_{i}$ is measured as the logarithm of the average amount of rent subsidy that an individual received in three periods 
before the reform. More specifically, the rent subsidy is calculated as the difference between self-reported market value and the rent paid for a state-provided housing unit. A positive estimate of $\alpha_{3}$ provides additional evidence that the reform increased job mobility among state sector workers. The estimates in columns 2 indicate that a doubling of the average prereform rent subsidy corresponded with a 0.59 times increase in the log odds of leaving the state sector for private employment.

For an additional test of the hypothesis of the mobility effects of unbundling housing from employment, I exploit the fact that the effects of unbundling housing from employment must work at the individual level while loosening credit constraints can affect other household members who are not working for the state sector. I separate out individuals living in state-owned housing before the reform and not employed in the state sector from those individuals who are residing in a state-owned housing unit and state employed. This separation provides an additional test for whether the impact of the reform on labor mobility can be attributed to the unbundling of housing from state employment.

More specifically, I estimate the following fixed-effects logit equation,

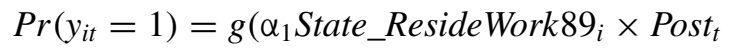

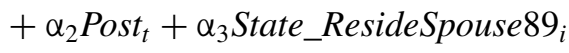

$$
\begin{aligned}
& \left.\times \text { Post }_{t}+\boldsymbol{\alpha}_{\mathbf{4}} \mathbf{x}_{\mathbf{i t}}+\gamma_{i}+\epsilon_{i t}\right) \text {, }
\end{aligned}
$$

where State_ResideSpouse 89 is an indicator that takes a value of 1 for residents of public housing who are not state employed; these individuals are the spouses of workers who received housing allocations from their employers and are excluded from State_ResideWork89. In this regression, the dependent variable is an indicator that takes a value of 1 if the individual is working. ${ }^{31}$ Because the CHNS does not ask individuals directly if they changed firms, I use employment status to capture the job mobility of individuals who were residing in state-owned housing but not employed in the state sector. ${ }^{32}$ A negative estimate of the coefficient on State_ResideWork $89 \times$ Post supports the hypothesis that the prereform system of employer-provided housing reduced job mobility. These individuals should be more likely to exit the labor force if they no longer rely on their jobs for housing. Furthermore, the mobility of spouses of individuals who received housing from their state employers should not be affected by the reform so coefficient estimates on State_ResideSpouse $89 \times$ Post equal to 0 would provide further support for the validity of the bundling hypothesis. The results in column 3 of table 5 show that the coefficient on State_ResideWork $89 \times$ Post is negative and significant at the $5 \%$ level and that the coefficient on

\footnotetext{
31 The mean of the dependent variable in the sample is $87 \%$.

32 It would not make sense to estimate equation (12) with the dependent variable as private wage employment because individuals for whom State_ResideSpouse $89=1$ are by definition not employed in the state sector.
}

State_ResideSpouse $89 \times$ Post is small in magnitude and not significantly different from 0 .

I also examine the impact of heterogeneity in prereform rent subsidies on employment status for state employees and non-state-employed spouses. I estimate

$$
\begin{aligned}
\operatorname{Pr}\left(y_{i t}=1\right)= & g\left(\alpha_{1} \text { State_ResideWork89 }_{i} \times \text { Post }_{t}\right. \\
& +\alpha_{2} \text { Post }_{t}+\alpha_{3}{\text { State_ResideWork } 89_{i}} \\
& \times \text { Post }_{t} \times \widetilde{h}_{i}+\alpha_{4} \text { State_ResideSpouse } 89_{i} \\
& \times \text { Post }_{t}+\alpha_{5}{\text { State_ResideSpouse } 89_{i}} \\
& \left.\times \text { Post }_{t} * \widetilde{h}_{i}+\alpha_{\mathbf{6}} \mathbf{x}_{\mathbf{i t}}+\gamma_{i}+\epsilon_{i t}\right)
\end{aligned}
$$

A negative estimate of $\alpha_{3}$ and a 0 estimate of $\alpha_{5}$ provide additional evidence that the reform increased labor mobility among state sector workers who had received subsidized housing benefits. Again, the results support the model's hypothesis on the impact of the housing reform on patterns of labor mobility. Column 4 displays a negative estimate of $\alpha_{3}$, as predicted, but it is not significant at the $10 \%$ level. While the estimate of $\alpha_{5}$ is not statistically different from 0 , it is fairly large in magnitude. A chi square test demonstrates that $\alpha_{1}$ and $\alpha_{3}$ are jointly significantly at the $10 \%$ level, while $\alpha_{4}$ and $\alpha_{5}$ are not jointly different from 0 at the $10 \%$ level.

The results presented in table 5 provide strong support for the idea that the unbundling of housing from state employment led to substantial increases in labor mobility. Individuals in state-owned housing are more likely to transition into private wage employment and out of the labor force following the reform than state-employed individuals who were not living in state-owned housing. Furthermore, the likelihood increases with the prereform size of the rent subsidy, which is consistent with the model's prediction that individuals with higher levels of rent subsidy also have higher unobserved ability outside the state sector. Finally, the results that separate residents of state-owned housing who are working in the state sector from those who are not state employed provide additional evidence that the housing reform enabled work transitions that reduced labor misallocation.

\section{B. Wage Growth}

Patterns in wage growth for individuals who change sectors provide a second test of the relevance of unbundling housing from state employment in explaining the effect of the housing reform on entrepreneurship. The model implies that the wage growth for individuals who leave the state sector should be higher before the reform than after the reform because individuals switching before 1994 needed to be compensated for the loss of housing benefits. This suggests examining the following first-difference equation over a selected sample of individuals who leave the state sector for a private job:

$$
\begin{aligned}
w_{i t}^{p}-w_{i, t-1}^{s}= & \beta_{0}+\beta_{1}\left(\text { State_ResideWork89 }_{i} \times \text { Post }_{t}\right) \\
& +\beta_{4}\left(x_{i t}-x_{i, t-1}\right)+\tau_{t}+v_{i t}
\end{aligned}
$$


where $w_{i t}^{p}$ is the monthly real earnings of the individual who is no longer in the state sector in period $t$, and $w_{i, t-1}^{s}$ is the monthly real wage in the state sector in period $t-1.33$ The treatment variable, State_ResideWork89, equals 1 if the individual was working for the state and living in state-owned housing in 1989. The comparison group comprises individuals who were working in the state sector but not living in state-owned housing in 1989. The specification also includes year dummies, denoted by $\tau_{t}$, rather than just a postreform indicator. This flexible specification for time captures differences in the intervals between surveys, which vary from two to four years. If bundling reduced mobility before the reform and was eliminated or reduced by the reform, then we would expect $\beta_{1}<0$. I also examine heterogeneity in the impact of the reform by the prereform levels of housing subsidy with the following regression:

$$
\begin{aligned}
w_{i t}^{p}-w_{i, t-1}^{s}= & \beta_{0}+\beta_{1}\left(\text { State_ResideWork } 89_{i} \times \text { Post }_{t}\right) \\
& +\beta_{2}\left(\text { State_ResideWork } 89_{i} \times \text { Post } \times \tilde{h}\right) \\
& +\beta_{4}\left(x_{i t}-x_{i, t-1}\right)+\tau_{t}+v_{i t} .
\end{aligned}
$$

A negative coefficient on $\beta_{2}$ suggests that heterogeneity in the provision of housing corresponded with the wage increases required for individuals to leave the state sector and supports the idea that state employer provided housing reduced labor mobility.

I estimate equation (15) with $w_{i t}^{p}, w_{i, t-1}^{s}$, and $\tilde{h}$ in levels. While the distributions of wages and rent subsidy appear to be suited for such a specification where both are measured in logs, the estimate of the triple interaction, State_ResideWork $89 \times$ Post $\times \widetilde{h}$, requires a strong assumption on the relationship between the dependent variable and $\widetilde{h}$. In this case, it is difficult to believe that a doubling of $\widetilde{h}$ at 10 RMB per month has the same percentage effect on wages as a doubling of $\widetilde{h}$ at $100 \mathrm{RMB}$ per month. In the levels specification, we would expect that an increase in $\widetilde{h}$ corresponds to the same amount of wage gain for an individual leaving the state sector. In other words, the model predicts a coefficient on State_ResideWork $89 \times$ Post $\times \widetilde{h}$ of -1 .

I also control for the differential trends in the returns of characteristics of individuals in the treatment group (State_ResideWork89 = 1) and state employees not living in public housing in 1989. Following section VIB, I estimate the propensity to be in public housing in 1989 with a sample of state-employed individuals. The results of this step are shown in column 2 of table A4. I include the propensity score and its interactions with Post and Post $\times \widetilde{h}$ to control for differences in observable characteristics between those in public housing and those in private housing.

Columns 1 and 2 table 6 of imply that public housing residents leaving the state sector needed $15 \%$ higher wages to compensate them for the loss of housing subsidies before the reform than after the reform. In the CHNS, the reported

\footnotetext{
${ }^{33}$ Fourteen extreme outliers of changes in wages of more than 400 RMB per hour are excluded.
}

\begin{tabular}{|c|c|c|c|c|}
\hline & \multicolumn{2}{|c|}{ Logarithm Specification } & \multicolumn{2}{|c|}{ Level Specification } \\
\hline & (1) & (2) & (3) & (4) \\
\hline $\begin{array}{l}\text { State_ResideWork89 } \\
\quad \times \text { Post }\end{array}$ & $\begin{array}{l}-0.153 \\
{[0.051]^{* * *}}\end{array}$ & $\begin{array}{l}-0.145 \\
{[0.054]^{* * *}}\end{array}$ & $\begin{array}{c}-18.851 \\
{[29.386]}\end{array}$ & $\begin{array}{l}-46.549 \\
{[27.337]^{*}}\end{array}$ \\
\hline $\begin{array}{l}\text { Propensity } \\
\quad \times \text { Post }\end{array}$ & & $\begin{array}{c}0.086 \\
{[0.172]}\end{array}$ & & $\begin{array}{l}32.266 \\
{[76.879]}\end{array}$ \\
\hline State_ResideWork89 & & & -0.201 & -0.323 \\
\hline $\begin{array}{l}\text { Propensity } \\
\quad \times \text { Post } \times \tilde{h}\end{array}$ & & & & $\begin{array}{c}{[0 . / 21]} \\
0.597\end{array}$ \\
\hline Observations & 244 & 226 & 256 & 238 \\
\hline Adjusted $R^{3}$ & 0.15 & 0.17 & 0.10 & 0.11 \\
\hline
\end{tabular}

TABLE 6.-FIRST-DifFERENCE Estimates OF WAGE GROWTH OF FORMER STATE EMPLOYEES

Significant at the ${ }^{* * *} 1 \%$ level, ${ }^{* *} 5 \%$ level, and ${ }^{*} 10 \%$ level. Robust standard errors clustered by household in brackets. Propensity is the estimated propensity score of being in the treatment group. $h$ is the average amount of rent subsidy received in the periods prior to the reform. Regressions also control for a firstdifference quadratic in age, a constant term, and year dummies. The sample includes heads and spouses who left the state sector.

value of the rental subsidy was approximately $23 \%$ of an individual's total wages in the prereform period, so the coefficient estimates correspond fairly well with the idea that the value of housing benefits that state workers received influenced their job tenure decisions. In the level specification in column 4 , an individual needed a wage gain of $47 \mathrm{RMB}$ more prior to the reform than after, and this is not statistically different from the average monthly value of the rental subsidy (67 RMB). Furthermore, in the specifications that include State_ResideWork $89 \times$ Post $\times \widetilde{h}$ in columns 3 and 4, the coefficient estimates on the triple interaction are negative, but they are not statistically different from 0 at the $10 \%$ level. In column 4, the point estimate of the triple interaction is not statistically different from the predicted value of -1 .

The empirical evidence supports the hypothesis that the system of housing provision by state work units reduced mobility before the reform and that the housing reform removed this barrier to mobility. Both tests give consistent support for the argument that the reduction in housing benefits associated with state jobs can explain at least part of the increase in self-employment following housing reform.

\section{Testing Credit Constraints}

\section{A. Appreciation in Housing Prices}

The model suggested that a positive relationship between capital investment or entry into entrepreneurship and postreform gains in housing wealth would provide evidence that individuals were accessing the value associated with their state-owned housing to alleviate credit constraints. I use heterogeneity in housing price appreciation across provinces and time to test for credit constraints. ${ }^{34}$ The data set on housing prices is discussed in appendix C. Changes in housing prices

\footnotetext{
${ }^{34}$ Hurst and Lusardi (2004) used fluctuations in housing equity as exogenous changes in wealth to analyze the impact of credit constraints on entrepreneurship. They found that wealth had no effect on the probability of entrepreneurship in the United States. In contrast, using a finer geographic unit of analysis, Fairlie and Krashinsky (2006) did find that appreciation in housing prices predicted entrepreneurship in the United States.
} 
Table 7.-Impact of Housing Price Appreciation on Self-Employment and Capital

\begin{tabular}{|c|c|c|c|c|c|c|}
\hline & \multicolumn{2}{|c|}{ FE Logit } & \multicolumn{2}{|c|}{ FE Logit } & \multicolumn{2}{|c|}{ Fixed Effects } \\
\hline & \multicolumn{2}{|c|}{$\overline{\text { Self-Employment }}$} & \multicolumn{2}{|c|}{$\overline{\text { Positive Capital }}$} & \multicolumn{2}{|c|}{$\overline{\log (\text { Capital })}$} \\
\hline & $\begin{array}{c}\text { Control }=\text { State } \\
\text { (1) }\end{array}$ & $\begin{array}{l}\text { Private } \\
\text { (2) }\end{array}$ & $\begin{array}{l}\text { State } \\
(3)\end{array}$ & $\begin{array}{l}\text { Private } \\
\text { (4) }\end{array}$ & $\begin{array}{l}\text { State } \\
(5)\end{array}$ & $\begin{array}{l}\text { Private } \\
\text { (6) }\end{array}$ \\
\hline \multirow[t]{2}{*}{ State_Resident $89 \times$ Post $\times \Delta q$} & 4.103 & 1.981 & 6.837 & 6.859 & 7.508 & 7.522 \\
\hline & {$[0.960]^{* * *}$} & {$[0.964]^{* *}$} & {$[2.515]^{* * *}$} & {$[0.696]^{* * *}$} & {$[3.161]^{* *}$} & {$[0.948]^{* * *}$} \\
\hline \multirow[t]{2}{*}{ State_Resident $89 \times$ Post } & 1.432 & 2.039 & 1.389 & 0.826 & 1.833 & 1.863 \\
\hline & {$[0.704]^{* *}$} & {$[0.492]^{* * *}$} & {$[0.229]^{* * *}$} & {$[0.451]^{*}$} & {$[0.663]^{* *}$} & {$[0.960]^{*}$} \\
\hline \multirow[t]{2}{*}{ Post $\times \Delta q$} & -0.856 & 1.024 & -1.624 & -1.485 & -1.828 & -1.572 \\
\hline & [1.423] & {$[0.806]$} & [2.126] & [1.437] & [2.423] & [1.954] \\
\hline \multirow[t]{2}{*}{ Post } & -0.806 & -1.281 & -2.192 & -1.507 & -2.028 & -1.920 \\
\hline & [0.957] & [0.863] & {$[0.262]^{* * *}$} & {$[0.267]^{* * *}$} & {$[0.128]^{* * *}$} & {$[0.498]^{* * *}$} \\
\hline Observations & 368 & 854 & 870 & 1,180 & 911 & 1,286 \\
\hline
\end{tabular}

$\Delta \mathrm{q}$ refers to province-level changes in housing prices. Additional controls are a quadratic in age and fixed effects. The capital regressions also include a constant term.

after the reform determine the housing wealth realized by the new home owners.

I estimate the following equation:

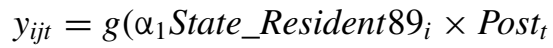

$$
\begin{aligned}
& +\alpha_{2} \text { State_Resident } 89_{i} \times \text { Post }_{t} \times \Delta q_{j t}+\alpha_{3} \text { Post }_{t} \\
& \left.\times \Delta q_{j t}+\alpha_{4} \text { Post }_{t}+\alpha_{5} x_{i j t}+\gamma_{i}+\epsilon_{i j t}\right),
\end{aligned}
$$

where $\Delta q_{j t}$ represents changes in housing prices in province $j$ and time $t .{ }^{35}$ The estimate of $\alpha_{2}$ is identified by differences in housing price appreciation across provinces and across time. Because the alleviation of credit constraints can affect other members of a household, the analysis in this section defines treatment at the couple level. I examine two dependent variables: self-employment and capital. When $y_{i j t}$ is the self-employment status of individual $i$ or whether individual $i$ owns productive assets, I estimate the equation with a fixed-effects logit. When $y_{i j t}$ is the logarithm of the amount of productive assets owned by household $i$, a fixed-effects linear regression is estimated. The standard errors are adjusted to allow clustering at the province level. Positive estimates of $\alpha_{2}$ support the hypothesis that the reform increased entrepreneurship by relaxing capital constraints.

Table 7 presents the results of equation (16). Columns 1 and 2 suggest that a 1 standard deviation increase in housing price appreciation (13\%) following the reform increases the relative log odds of the treatment group entering self-employment by 0.53 and 0.26 times, respectively. The coefficients on the triple interaction in columns 3 through 6 in table 7 are significant and positive. For existing capital owners, a 1-standard deviation increase in housing prices corresponds with an increase in capital for treated households of over $150 \%$ above the increase in capital for similar households living in areas of stagnant house prices. The fixed-effects logit estimates of positive capital ownership confirm that the reform had a larger

\footnotetext{
${ }^{35}$ I do not include State_Resident $89_{i} \times \Delta q_{j t}$, which would reflect the impact of changes in housing prices for the treatment group before the reform. First, it is not possible because the data series for $q_{j t}$ begin in 1993. Second, the theoretical model suggests that housing prices should not affect the treatment group before the reform because by definition, treated individuals do not own a home before the reform.
}

effect on capital in areas where house prices experienced greater growth. The coefficients on State_Resident $89 \times$ Post $\times$ $\Delta q$ in columns 3 and 4 indicate that a 1 -standard deviation increase in house prices led to an increase in the relative log odds of a transition from zero capital to positive capital ownership by approximately 0.85 times.

The results in this section rely on the strong assumption that changes in housing prices are orthogonal to other determinants of business investment and entrepreneurship. Appreciation in housing prices may be correlated with other changes in conditions across provinces and time, so the estimate of $\alpha_{2}$ may reflect changes other than appreciation in home values. For example, an inflow of workers to an area due to local labor demand will lead to an increase in housing prices and affect individuals' decisions regarding entrepreneurship in ways other than through the value of their homes. I attempt to deal with this issue by including changes in average wages and consumer prices (as well as their interactions with State_Resident $89 \times$ Post) to capture changes in local economic conditions. The additional control variables do not have a large effect on the estimates of the coefficients of interest. 36

\section{B. Private Property Rights and Access to Capital of Entrepreneurs}

Another test for credit market failures involves an examination of the impact of the housing reform on capital invested in small business enterprises. In an environment with credit constraints, we would expect the postreform ability to capitalize on housing to increase asset investment in household businesses. However, if the unbundling of housing from state employment increased entry into entrepreneurship, then the housing reform could increase capital even in the absence of credit constraints. To isolate the relevance of credit constraints on entrepreneurship and avoid the confounding influence of unbundling benefits from employment, I consider a sample limited to households that either operated a small business or had a self-employed member in 1993. In the

\footnotetext{
${ }^{36}$ Results availble from the author.
} 
TABLE 8.-IMPACT OF REFORM ON CAPITAL

\begin{tabular}{ccccc}
\hline \hline & \multicolumn{2}{c}{ Full Sample of Households } & \multicolumn{2}{c}{1993 Business Households } \\
\cline { 2 - 4 } & $\begin{array}{c}\text { Control }=\text { State } \\
\text { (1) }\end{array}$ & $\begin{array}{c}\text { Control }=\text { Private } \\
(2)\end{array}$ & $\begin{array}{c}\text { Control = State } \\
(3)\end{array}$ & Control = Private \\
$(4)$
\end{tabular}

a quadratic in the age of the head, and a constant term.

limited sample, a positive effect of the reform on the amount of capital owned by households provides evidence that the reform's alleviation of credit constraints is independent of unbundling employment and housing.

The results are presented in table 8 . Columns 1 and 2 display the estimates for the full sample, and columns 3 and 4 correspond to the limited sample of households involved in a small business in 1993. In columns 1 and 2, the dependent variable is the logarithm of the household's total market value of the professional and productive equipment that they own plus 1.37 The coefficient estimates of State_Resident $89 \times$ Post for the full sample and the limited sample are all significant and with somewhat larger estimates for 1993 business households. For the full sample, the coefficients indicate that the reform increased treated households' ownership of productive assets by $340 \%$ relative to privately employed households and by around $200 \%$ relative to state-employed households in privately owned housing. The corresponding estimates for households already engaged in small business activities are around 500\%. They indicate that the increase in capital is not merely driven by entry into entrepreneurship. The magnitude of the impact of the housing reform on capital is quite large, but this is not surprising given the low initial levels of capital investment and the large difference between the market value and the government price charged on the homes. While there is a positive relative effect of the reform on the value of capital owned by the treatment group, the coefficient on Post is negative and significant. This suggests that there was a trend toward decreasing investment in small businesses among nontreatment households.

Comparing the impact of the reform on capital for the full sample and the sample limited yields a lower-bound estimate of the contribution of the relaxation of credit constraints on the increase in capital investment by the treatment group. The total effect of the reform on capital owned by treated households is given by the coefficients on State_Resident $89 \times$ Post in columns 1 and 2 in table 8 . The lower-bound contribution of the relaxation of credit constraints can be measured with the corresponding coefficients in columns 3 and 4. Households that engaged in a business in 1993 make up about 5\% of treatment households, and their average level of capital holdings in 1993 is 610 RMB. These numbers, combined

\footnotetext{
${ }^{37}$ Other specifications that demonstrate that the results are not driven by a mass of zero values in the dependent variable are available from the author.
}

with the average capital owned by all treatment households shown in table 1 , suggest that at least $65 \%$ of the total increase in capital of the treatment group can be attributed to the relaxation of credit constraints associated with the housing reform. The evidence suggests that the alleviation of credit constraints played a larger role in the expansion of investment in business enterprises than the unbundling of housing provision from state employment.

\section{Conclusion}

This paper presents new evidence on the economic implications of employer-provided housing in the state sector. My results suggest that the participation of state employers in the housing market introduced distortions to individuals' labor market choices. By deterring job mobility and the private accumulation of property, the prereform system of in-kind housing benefits created inefficiencies in the labor market. The empirical evidence indicates that the sale of state-owned housing encouraged entrepreneurship among individuals who received the opportunity to purchase the homes that they had been renting from their state employers. This paper provides a framework for understanding the two mechanisms through which the privatization of state housing assets can increase entrepreneurship and aggregate productivity. One explanation is that the conversion of state assets to private property allowed individuals to capitalize on the value associated with their real estate and hence relieved credit constraints. The other explanation highlights the potential impact of unbundling housing provision from employment on job mobility. While it is impossible to use the reform to examine either credit constraints or the bundling of housing and employment in isolation, the model yielded predictions to test the relevance of each argument.

The empirical results support the idea that both mechanisms played a role in the positive impact of the reform on entrepreneurship among the former tenants of state housing. This work provides some evidence that credit markets failed to provide efficient levels of capital for small businesses in China, and this affected both entry into entrepreneurship and the accumulation of productive assets. While individuals respond to the total compensation package and make optimal choices, the bundling of housing benefits with employment in the state sector resulted in matches between workers and 
employers that were not the most productive from the perspective of a social planner. Furthermore, a system that allows state bureaucrats to allocate housing units among state sector workers generates the potential for corruption. This work has policy relevance for other developing countries that continue to provide subsidized state-owned housing for workers in civil service and state-owned enterprises. Policymakers have the opportunity to encourage small businesses by promoting private ownership of assets and increasing small business lending in the formal sector.

The program represented a large shift in the ideology of the government regarding private property rights as it encouraged private ownership of homes. It succeeded in turning China into a country with one of the highest rates of home ownership in the world. I have argued that this reform allowed constrained individuals with entrepreneurial ability the opportunity to begin business ventures and increased labor mobility out of the sizable state sector. However, an understanding of the returns to privatizing public housing assets in other countries requires more analysis on the legal and financial institutions that are necessary for such a housing program to have an effect.

\section{REFERENCES}

Acemoglu, Daron, Simon Johnson, and James Robinson, "Colonial Origins of Comparative Development: An Empirical Investigation," American Economic Review 91 (2001), 1369-1401.

Allison, Paul, "Comparing Logit and Probit Coefficients across Groups," Sociological Methods and Research 28 (1999), 186-208.

Amemiya, Takeshi, Advanced Econometrics (Cambridge, MA: Harvard University Press, 1985)

Arora, Raksha, "Borrowing Behavior in China," Gallup Poll, March 29, 2005.

Banerjee, Abhijit, and Ester Duflo, "Do Firms Want to Borrow More? Testing Credit Constraints Using a Directed Lending Program," Centre for Economic Policy Research discussion paper no. 4681 (2004).

Banerjee, Abhijit, and Andrew Newman, "Occupational Choice and the Process of Development," Journal of Political Economy 101 (1993), 274-298.

Bertrand, Marianne, Ester Duflo, and Sendhil Mullainathan, "How Much Should We Trust Differences-in-Differences Estimates?" Quarterly Journal of Economics 119 (2004), 249-275.

Besley, Timothy, "Property Rights and Investment Incentives: Theory and Evidence from Ghana," Journal of Political Economy 103 (1995), 903-937.

Buchmueller, Thomas, and Robert Valletta, "The Effects of EmployerProvided Health Insurance on Worker Mobility," Industrial and Labor Relations Review 49 (1996), 439-455.

Davis, Deborah, "Urban Households: Supplicants to a Socialist State," in Deborah Davis and Stevan Harrell (Eds.), Chinese Families in the Post-Mao Era (Los Angeles: University of California Press, 1993).

De Mel, Suresh, David McKenzie, and Christopher Woodruff, "Returns to Capital in Microenterprises: Evidence from a Field Experiment," Quarterly Journal of Economics 123 (2008), 1329-1372.

De Soto, Hernando, The Mystery of Capital: Why Capitalism Triumphs in the West and Fails Everywhere Else (New York: Basic Books, 2000).

Djankov, Simeon, Yingyi Qian, Gerard Roland, and Ekaterina Zhuravskaya, "Who Are China's Entrepreneurs?" American Economic Review, Papers and Proceedings 96 (2006), 348-352.

Evans, David, and Boyan Jovanovic, "Estimated Model of Entrepreneurial Choice under Liquidity Constraints," Journal of Political Economy 97 (1989), 808-827.

Fairlie, Robert, and Harry Krashinsky, "Liquidity Constraints, Household Wealth, and Entrepreneurship Revisited," IZA discussion paper no. 2201 (2006)
Feder, Gershon, Lawrence Lau, Justin Lin, and Xiaopeng Luo, "The Determinants of Farm Investment and Residential Construction in Post-Reform China," Economic Development and Cultural Change, 41 (1992), 1-26.

Field, Erica, "Property Rights and Investment in Urban Slums," Journal of the European Economic Association 3 (2005), 279-290.

"Entitled to Work: Urban Property Rights and the Labor Supply in Peru," Quarterly Journal of Economics 122 (2007), 1561-1602.

Fishback, Price, "Economics of Company Housing: Historical Perspectives from the Coal Fields," Journal of Law, Economics, and Organization 8 (1992), 346-365.

Galiani, Sebastian, and Ernesto Schargrodsky, "Property Rights for the Poor: Effects of Land Titling," Journal of Public Economics 94 (2010), 700-729.

Giles, John, Albert Park, and Juwei Zhang, "What Is China's True Unemployment Rate?" China Economic Review 16 (2005), 149-170.

Gruber, Jonathan, and Brigitte Madrian, "Health Insurance, Labor Supply, and Job Mobility: A Critical Review of the Literature," NBER working paper no. 8817 (2002).

"Guangxi's Housing Reform Success," China News Analysis, October 1, 1998.

Guo, Yutao, and Huiming Mu, Fang Dichan Diya [Housing collateral] (Beijing: China University of Political Science and Law Press, 1998).

Hughes, Gordon, and Barry McCormick, "Housing Markets, Unemployment and Labour Market Flexibility in the UK," European Economic Review 31 (1987), 615-641.

Hurst, Erik, and Annamaria Lusardi, "Liquidity Constraints, Household Wealth, and Entrepreneurship," Journal of Political Economy 112 (2004), 319-347.

Iyer, Lakshmi, Xin Meng, and Nancy Qian, "Unbundling Property Rights: The Impact of Urban Housing Reforms on Labor Mobility and Savings in China," unpublished working paper (2009).

Kapur, Kanika, "The Impact of Health on Job Mobility: A Measure of Job Lock," Industrial and Labor Relations Review 51 (1998), 282-298.

Kynge, James, "Borrowing Sustains Middle Classes in China's Long March to Prosperity," Financial Times, December 28, 2002.

$\mathrm{Li}$, Jianjin, Zhongguo dixia jinrong guimo yu hongguan jingji yingxiang yanjiu [Research on the scale of underground financing and its economic effects]. (Beijing: Zhongguo jinrong chubanshu, 2005).

Logan, John, and Min Zhou, "Market Transition and the Commodification of Housing in Urban China," International Journal of Urban and Regional Research 20 (1996), 400-421.

Madrian, Brigitte, "Employment-Based Health Insurance and Job Mobility: Is There Evidence of Job Lock?" Quarterly Journal of Economics 109 (1994), 27-54.

McKenzie, David, and Christopher Woodruff, "Do Entry Costs Provide an Empirical Basis for Poverty Traps? Evidence from Mexican Microenterprises," Economic Development and Cultural Change 55 (2006), 3-42.

Paulson, Anna, and Robert Townsend, "Entrepreneurship and Financial Constraints in Thailand," Journal of Corporate Finance 10 (2004), 229-262.

Pudney, Stephen, and Limin Wang, "Housing Reform in Urban China: Efficiency, Distribution and the Implications for Social Security," Economica 62 (1995), 141-159.

Rosenbaum, Paul, and Donald Rubin, "The Central Role of the Propensity Score in Observational Studies for Causal Effects," Biometrika 70 (1983), 41-55.

Svarer, Michael, Michael Rosholm, and Jakob Roland Munch, "Rent Control and Unemployment Duration," Journal of Public Economics 89 (2004), 2165-2181.

Udry, Christopher, and Santosh Anagol, "Return to Capital in Ghana," American Economic Review Papers and Proceedings 96 (2006), 388-393.

United Nations Secretariat and United Nations Centre for Human Settlements, Compendium of Human Settlement Statistics (New York: United Nations Publications, 2001).

Wang, Shing-Yi, "Credit Constraints, Job Mobility and Entrepreneurship: Evidence from a Property Reform in China," DRI working paper no. 30 (2008).

"State Misallocation and Housing Prices: Theory and Evidence from China," American Economic Review 101 (2011), 2081-2107. 
Wang, Ya-ping, and Alan Murie, Housing Policy and Practice in China (New York: St. Martin's Press, 1999).

Watts, Jonathan, "Pawn Again," South China Morning Post, February 1, 2005.

Wooldridge, Jeffrey, Econometric Analysis of Cross Section and Panel Data (Cambridge, MA: MIT Press, 2002a).

"Inverse Probability Weighted M-Estimation for Sample Selection, Attrition and Stratification," Portuguese Economic Journal 1 (2002b), 587-590.

\section{APPENDIX A}

\section{Evidence on Rent Subsidy and Wage Compensation}

The relationship between employer-provided housing and job mobility implied by the model depends on the system of housing allocation to state employees in China. The key assumption is that wages in the state sector are not fully adjusted based on the amount of rental subsidy that an individual receives. Wages in the state sector in China are set according to official tables that depend on observable characteristics such as occupation and tenure. Thus, if two individuals with identical characteristics work in the same position at a state-owned enterprise, their wages will be equal regardless of differences in the value of their housing allocations. In this appendix, I present empirical evidence to support the assumption that the wages of state employees with similar characteristics are not adjusted to offset differences in their housing benefits. First, I examine whether the wages of state employees with public housing are significantly lower than similar state sector workers living in private housing. Second, I analyze whether the amount of rental subsidy is negatively correlated with the wages of state employees conditional on observable characteristics.

The results of the first test are displayed in columns 1 and 2 of table A1 in the Table Appendix. The dependent variable is the logarithm of an individual's wage. The sample is limited to state employees in the prereform waves. The inclusion of one-digit occupation fixed effects in column 2 absorbs any effects from differences in occupations of treatment individuals and nontreated state employees. The coefficient estimates of State_ResideWork89 are similar for both specifications, and neither is significantly different from 0 . Conditional on observable characteristics such as age and education, the average wages of employees in state-owned enterprises are the same regardless of whether they receive a subsidized housing allocation. Furthermore, the point estimates are quite small. The average prereform rent subsidy was worth $23 \%$ of the wages of a state employee, and wage differences of $1.5 \%$ and $1.6 \%$ implied by columns 1 and 2 , respectively, are considerably smaller than the average value of the rental subsidies. I also include the number of household members who are cadres to capture connections in the state sector. The estimates indicate that state connections do not influence wages, and this supports the assumption of the model that $\mu_{i}$ is not perfectly correlated with $\psi_{i}$.

The second test uses the actual amount of rent subsidy rather than just a binary division between whether a person lives in a state-subsidized home. In the estimates in columns 3 and 4 in table A1, the dependent variable is the logarithm of the rent subsidy received in each year plus 1 and the sample is limited to prereform years. In column 3, the positive and significant impact of cadres in the household on the prereform amount of rent subsidy confirms that unobserved connections, $\mu_{i}$, determine a significant portion of the variation in $\widetilde{h}_{i}$. While the lack of significance of the coefficient on Household Cadre in the estimation with household fixed effects provides some support for the theoretical assumption that people's unobserved connections in the state sector are time invariant, the standard errors are too large to be conclusive. The coefficients on Monthly Wage, which is measured as the logarithm of a household's real monthly wages, are economically small and statistically equivalent to 0.38 The point estimate with household fixed effects indicates that a doubling of wages corresponds to a decrease in rent subsidies of $4.2 \%$. Overall, the results reinforce the findings of the first test. The correlation between wages and housing benefits is not statistically different from 0 , and the magnitude of the relationship is too small to support the idea that wages are adjusted to offset differences in the value of the state housing allocation.

${ }^{38}$ Measuring the wages and rent subsidies in levels, which relaxes of the assumptions associated with a log-log regression, produces similar results.

\section{APPENDIX B}

\section{Impact of the Reform on Home Ownership}

Figure 1 demonstrates that the trends in home ownership were fairly parallel for the two groups before and after the state sale of housing. ${ }^{39}$ Table A2 in the Table Appendix displays coefficients of fixed-effects logit estimates of equation (8), where the dependent variable is home ownership. The housing program increased the log odds of home ownership for the treatment group relative to the control groups by approximately five to seven times. Overall, the results in Table A2 confirm that the housing program was successful in increasing the home ownership rate among public housing tenants.

\section{APPENDIX C}

\section{Supplementary Data Sources}

Data on housing prices that begin as early as the mid-1990s are not common. To my knowledge, the only aggregate series that extends as far back as 1993 are provincial statistics on the value and the floor space of residential homes sold in the China Statistical Yearbooks, published by the National Bureau of Statistics. Because my focus is on urban areas, I use the price series covering cities, towns, and industrial and mining areas rather than entire provinces. The average price per square meter of residential space is constructed as the total value divided by the floor space sold from 1993 to 2000.40 Other province-level data used as controls, such as average wages and the urban consumer price index, are also from the China Statistical Yearbooks. The average province-level wages and housing prices are converted into real 1990 RMB using the GDP deflator for mainland China from the United Nations. The appreciation in the price of residential housing is constructed as the percentage change in the real average price per square meter since the last survey.

\section{TABLE APPENDIX}

TABle A1.-WAges and Housing Benefits of State Employees IN PREREFORM YEARS (1989-1993)

\begin{tabular}{lccccc}
\hline \hline & \multicolumn{2}{c}{ Logarithm of Wages } & & \multicolumn{2}{c}{ Logarithm of Rent Subsidy } \\
\cline { 2 - 3 } \cline { 5 - 6 } & OLS & OLS & & OLS & FE \\
& $(1)$ & $(2)$ & & $(3)$ & $(4)$ \\
\hline State_ResideWork89 & -0.015 & -0.016 & & \\
Monthly wage & {$[0.042]$} & {$[0.041]$} & & & \\
& & & & 0.077 & -0.042 \\
Household cadre & 0.024 & 0.007 & & 0.152 & $0.064]$ \\
Occupation FE & {$[0.018]$} & {$[0.019]$} & & {$[0.090]^{*}$} & {$[0.083]$} \\
Observations & No & Yes & & No & No \\
Adjusted $R^{2}$ & 2,805 & 2,722 & & 1,456 & 1,456 \\
\cline { 1 - 2 } & 0.14 & 0.14 & & 0.28 & 0.80 \\
\hline
\end{tabular}

Significant at the ${ }^{* * *} 1 \%$ level, ${ }^{* *} 5 \%$ level, ${ }^{*} 10 \%$ level. Robust standard errors clustered by household in brackets. The log wage regressions in columns 1 and 2 are at the individual level, and the log rent subsidy regressions in columns 3 and 4 are at the household level. The regressions also include indicators for year and province, a quadratic in age, and a constant term. In addition, the OLS regressions in columns 1 and 2 include education and a male indicator, and column 3 includes the education of the head of house.

${ }^{39} \mathrm{~A}$ breakdown by the particular definitions of the treatment group, the state control group, and the private control group provides similar support for the parallel trends assumption.

40 Urban housing price data in 2004 are excluded because of clear evidence of at least one error in the published data in that year. There is a dramatic drop in the value of residential sales in urban areas for at least one province (Liaoning) by a factor of 100, but no corresponding drop for the same series in the flanking years, the area of residential homes sold in urban areas in 2004, province-wide housing prices, or the prices of commercial buildings. 
TABLE A2.-IMPACT OF THE REFORM ON HOME OWNERSHIP

\begin{tabular}{lcc}
\hline \hline & $\begin{array}{c}\text { Control = State } \\
\text { Workers } \\
(1)\end{array}$ & $\begin{array}{c}\text { Control = Private } \\
\text { Workers } \\
\end{array}$ \\
\hline State_Resident89 $\times$ Post & 7.224 & $(2)$ \\
Post & {$[1.323]^{* * *}$} & 4.814 \\
Observations & -4.213 & {$[0.642]^{* * *}$} \\
& {$[1.210]^{* * *}$} & -1.198 \\
& 1,418 & {$[0.577]^{* *}$} \\
\hline
\end{tabular}

Significant at the ${ }^{* * *} 1 \%$ level, ${ }^{*} 5 \%$ level, ${ }^{*} 10 \%$ level. Robust standard errors clustered by household in brackets. Additional controls are a quadratic in age and individual fixed effects.

TABLE A3.-FiXED-EFFECTS LOGIT EstimATES OF RESIDENTIAL MOVE OF HOUSEHOLD

\begin{tabular}{lcc}
\multicolumn{3}{c}{ MOVE OF HOUSEHOLD } \\
\hline & $\begin{array}{c}\text { Control }=\text { State } \\
(1)\end{array}$ & $\begin{array}{c}\text { Control }=\text { Private } \\
(2)\end{array}$ \\
\hline State_Resident89 $\times$ Post & 1.385 & 1.111 \\
& {$[0.407]^{* * *}$} & {$[0.329]^{* * *}$} \\
Post & 0.018 & 0.272 \\
& {$[0.354]$} & {$[0.265]$} \\
Observations & 561 & 765
\end{tabular}

Coefficients shown. Significant at the ${ }^{* * *} 1 \%$ level, ${ }^{* *} 5 \%$ level, ${ }^{*} 10 \%$ level. Standard errors clustere by household in brackets. Regressions also include a quadratic in age of the head of house.

TABLE A4.-Estimates OF THE PROPENSITY SCORE OF STATE_RESIDEWORK89

\begin{tabular}{lcc}
\hline \hline & Full Sample & State-Employed Sample \\
& $(1)$ & $(2)$ \\
\hline Age & 0.038 & 0.117 \\
& {$[0.057]^{* * *}$} & {$[0.086]$} \\
Age & & -0.000 \\
& -0.001 & {$[0.001]$} \\
Years of education & {$[0.000]^{* * *}$} & 0.097 \\
& 0.197 & {$[0.023]^{* * *}$} \\
Male & {$[0.019]^{* * *}$} & -0.791 \\
& -0.356 & {$[0.127]^{* * *}$} \\
Household cadre & {$[0.057]^{* * *}$} & 0.371 \\
& 0.711 & {$[0.2107]^{*}$} \\
Observations & {$[0.204]^{* * *}$} & 1,017
\end{tabular}

Coefficients of logit estimates shown. Significance at the ${ }^{* * *} 1 \%$ level, ${ }^{*} 5 \%$ level, ${ }^{*} 10 \%$ level. Robus standard errors clustered by household in brackets. Additional controls are province indicators and a constant term.

TABle A5.-Logit Estimates of AtTrition

\begin{tabular}{|c|c|c|c|c|c|}
\hline & $\begin{array}{c}\operatorname{Pr}(\text { Stay 1991) } \\
\text { (1) }\end{array}$ & $\begin{array}{c}\operatorname{Pr}(\text { Stay } 1993) \\
(2)\end{array}$ & $\begin{array}{c}\operatorname{Pr}(\text { Stay 1997) } \\
\text { (3) }\end{array}$ & $\begin{array}{c}\operatorname{Pr}(\text { Stay 2000) } \\
(4)\end{array}$ & $\begin{array}{c}\operatorname{Pr}(\text { Stay 2004) } \\
\text { (5) }\end{array}$ \\
\hline State_Resident 89 & $\begin{array}{c}0.004 \\
{[0.015]}\end{array}$ & $\begin{array}{c}-0.009 \\
{[0.023]}\end{array}$ & $\begin{array}{c}-0.087^{* * *} \\
{[0.031]}\end{array}$ & $\begin{array}{c}-0.021 \\
{[0.029]}\end{array}$ & $\begin{array}{c}0.020 \\
{[0.042]}\end{array}$ \\
\hline Age & $\begin{array}{c}-0.002 \\
{[0.004]}\end{array}$ & $\begin{array}{c}0.006 \\
{[0.006]}\end{array}$ & $\begin{array}{c}0.025^{* *} \\
{[0.010]}\end{array}$ & $\begin{array}{r}-0.034^{*} \\
{[0.018]}\end{array}$ & $\begin{array}{c}0.003 \\
{[0.020]}\end{array}$ \\
\hline $\mathrm{Age}^{2}$ & $\begin{array}{c}0.000 \\
{[0.000]}\end{array}$ & $\begin{array}{c}-0.000 \\
{[0.000]}\end{array}$ & $\begin{array}{c}-0.000^{* * *} \\
{[0.000]}\end{array}$ & $\begin{array}{c}0.000^{*} \\
{[0.000]}\end{array}$ & $\begin{array}{c}-0.000 \\
{[0.000]}\end{array}$ \\
\hline Education & $\begin{array}{r}-0.002^{*} \\
{[0.001]}\end{array}$ & $\begin{array}{c}0.001 \\
{[0.002]}\end{array}$ & $\begin{array}{c}-0.003 \\
{[0.003]}\end{array}$ & $\begin{array}{c}-0.003 \\
{[0.003]}\end{array}$ & $\begin{array}{c}-0.021^{* * *} \\
{[0.005]}\end{array}$ \\
\hline Male & $\begin{array}{c}0.004 \\
{[0.004]}\end{array}$ & $\begin{array}{c}-0.006 \\
{[0.006]}\end{array}$ & $\begin{array}{c}-0.004 \\
{[0.010]}\end{array}$ & $\begin{array}{c}0.003 \\
{[0.008]}\end{array}$ & $\begin{array}{c}0.022^{*} \\
{[0.013]}\end{array}$ \\
\hline Log(HH Size $)$ & $\begin{array}{c}0.025 \\
{[0.017]}\end{array}$ & $\begin{array}{c}0.069^{* *} \\
{[0.031]}\end{array}$ & $\begin{array}{c}0.025 \\
{[0.037]}\end{array}$ & $\begin{array}{c}0.050 \\
{[0.036]}\end{array}$ & $\begin{array}{c}0.031 \\
{[0.054]}\end{array}$ \\
\hline Married & $\begin{array}{c}0.077 \\
{[0.063]}\end{array}$ & $\begin{array}{c}0.052 \\
{[0.042]}\end{array}$ & $\begin{array}{c}-0.044 \\
{[0.038]}\end{array}$ & $\begin{array}{c}-0.008 \\
{[0.040]}\end{array}$ & $\begin{array}{c}0.064 \\
{[0.065]}\end{array}$ \\
\hline Observations & 1,861 & 1,475 & 1,148 & 835 & 816 \\
\hline
\end{tabular}

Average marginal effects shown. Robust standard errors clustered by household in brackets. Significant at the ${ }^{* * *} 1 \%$ level, ${ }^{* *} 5 \%$ level, ${ }^{*} 10 \%$ level. Additional controls are province fixed effects. 